\title{
DYNAMIC STATUTORY INTERPRETATION
}

\section{WILliam N. Eskridge, JR. $\dagger$}

Federal judges interpreting the Constitution typically consider not only the constitutional text and its historical background, but also its subsequent interpretational history, related constitutional developments, and current societal facts. Similarly, judges interpreting common law precedents normally consider not only the text of the precedents and their historical context, but also their subsequent history, related legal developments, and current societal context. In light of this, it is odd that many judges and commentators believe judges should consider only the text and historical context when interpreting statutes, the third main source of law. Statutes, however, should-like the Constitution and the common law-be interpreted "dynamically," that is, in light of their present societal, political, and legal context. ${ }^{1}$

Traditional doctrine teaches that statutes should not be interpreted dynamically. Prevailing approaches to statutory interpretation treat statutes as static texts. Thus, the leading treatise states that "[f]or the interpretation of statutes, 'intent of the legislature' is the criterion that is most often cited." This "intentionalist" approach asks how the legislature originally intended the interpretive question to be answered, or

(C) Copyright 1987 by William N. Eskridge, Jr. All rights reserved.

† Visiting Associate Professor of Law, Georgetown University Law Center.

I am very grateful to Bruce Ackerman, Alexander Aleinikoff, Daniel Farber, Owen Fiss, Philip Frickey, Hendrik Hartog, William Luneburg, William Nelson, Gary Peller, Robert Pitofsky, Richard Posner, Cass Sunstein, Laurens Walker, and Edward White for generous and constructive comments on earlier drafts of this Article. I presented a draft of the Article to faculty workshops at the University of Wisconsin Law School and the University of Minnesota Law School; I appreciate the many constructive comments and questions posed at those workshops, and this Article reflects the insights I gained from the experiences. (Remaining errors are my own.) I thank Craig Meredith and Laura Visser for research aid.

The central idea in the Article grew out of my work with Philip Frickey on our legislation materials, which will be published by the West Publishing Company in 1987 as Statutes and the Creation of Public Policy.

1 Compare R. Dworkin, Law's EmpIRe 313-54 (1986) (statutes should be interpreted similarly to the common law, with the judicial interpreter determining in each case what is the "best" application of the statute in light of current circumstances) with Brest, The Misconceived Quest for the Original Understanding, 60 B.U.L. REv. 204 (1980) (advocating a "nonoriginalist" interpretation of both statutes and the Constitution). Brest's Article is the source for the terminology - "intentionalist," "modified intentionalist," and "originalist" - used in the next paragraph of this Article.

2 2A Sutherland, Statutes and Statutory Construction $\S 45.05$ (4th ed. 1984). 
would have intended the question to be answered had it thought about the issue when it passed the statute. ${ }^{3}$ A "modified intentionalist" approach uses the original purpose of the statute as a surrogate for original intent, especially when the latter is uncertain; the proper interpretation is the one that best furthers the purpose the legislature had in mind when it enacted the statute.

Theoretically, these "originalist" approaches to statutory interpretation assume that the legislature fixes the meaning of a statute on the date the statute is enacted. The implicit claim is that a legislator interpreting the statute at the time of enactment would render the same interpretation as a judge interpreting the same statute fifty years later. This implication seems counterintuitive. Indeed, the legal realists argued this point earlier in the century. For example, gaps and ambiguities exist in all statutes, typically concerning matters as to which there was little legislative deliberation and, hence, no clear intent. As society changes, adapts to the statute, and generates new variations of the problem which gave rise to the statute, the unanticipated gaps and ambiguities proliferate. In such circumstances, it seems sensible that "the quest is not properly for the sense originally intended by the statute, [or] for the sense sought originally to be put into it, but rather for the sense which can be quarried out of it in the light of the new situation." Moreover, as time passes, the legal and constitutional context of the statute may change. Should not an interpreter "ask [her]self not only what the legislation means abstractly, or even on the basis of legislative history, but also what it ought to mean in terms of the needs and goals of our present day society[?]"6

s For general explanation of the intentionalist approach, see Lehigh Valley Coal Co. v. Yensavage, 218 F. 547, 553 (2d Cir. 1914) (L. Hand, J.); R. Posner, The Federal Courts: CRISIS AND Reform 286-93 (1985); Posner, Statutory Interpretation-in the Classroom and in the Courtroom, 50 U. CHI. L. REv. 800, 817-22 (1983) ("The judge should try to think his way as best he can into the minds of the enacting legislators and imagine how they would have wanted the statute applied to the case at bar."). A narrower approach emphasizes the statutory text to the exclusion of other contextual factors (such as legislative history). "Textualism" can be defended as the best evidence of what the legislature actually meant when it enacted the statute. See Easterbrook, Statutes' Domains, 50 U. CHI. L. Rev. 533 (1983).

- See, e.g., H. Hart \& A. Sacks, The Legal Process: Basic Problems in the Making and APpl.ICation of Law 1201 (tent. ed. 1958) (unpublished manuscript); Macey, Promoting Public-Regarding Legislation through Statutory Interpretation: An Interest Group Model, 86 Colum. L. Rev. 223 (1986). See generally R. Dickerson, The Interpretation and Application of Statutes (1975) (setting forth a coherent modified-intentionalist account of statutory interpretation).

- Llewellyn, Remarks on the Theory of Appellate Decision and the Rules or Canons about How Statutes Are to Be Construed, 3 VAND. L. REv. 395, 400 (1950) (emphasis deleted).

- Phelps, Factors Influencing Judges in Interpreting Statutes, 3 VaND. L. REv. 
The purpose of this Article is to explore the thesis that statutes, like the Constitution and the common law, should be interpreted dynamically. ${ }^{7}$ Part I sets forth a cautious model of dynamic statutory interpretation. It uses specific examples of dynamic interpretation to show how the model works. The Article accepts the traditional assumptions that a functioning representative democracy exists in our polity, that the legislature is the primary lawmaking body, and that in many cases statutory language will be sufficiently determinate to resolve a given case. ${ }^{8}$ Even under these conventional assumptions, however, original legislative expectations should not always control statutory meaning. This is especially true when the statute is old and generally phrased and the societal or legal context of the statute has changed in material ways.

Part II demonstrates that no good reason compels adherence to traditional originalist doctrine. Three major types of arguments have been invoked in favor of statutory intentionalism or modified intentionalism: (1) the formalist argument that the Constitution vests Congress with the exclusive power to create law or policy, leaving courts with no role but to carry out the intent (or purpose) of Congress; (2) the economic argument that statutes are contracts between interest groups and legislatures and as such must be enforced by judges (the "agents" of the legislature) according to their original terms and intent; and (3) the legal process argument that it is illegitimate for nonelected judges to make policy in a majoritarian political system by expanding upon the original meaning of statutes. None of these arguments, however, justifies unexceptioned statutory intentionalism when circumstances have changed and the statutory language is not determinate.

Part III describes the advantages of the proposed model of dynamic statutory interpretation over other current approaches to statutory interpretation. The Article argues that this model depicts what the Supreme Court typically does when it interprets statutes and that the

456,469 (1950).

7 This approach is related to, but stops far short of, the proposal in G. CalaBRESI, A CoMmon LAw FOR THE AGE of STATUTES (1982), that courts ought to be able to update statutes by overruling them. Calabresi's thesis has been criticized as inconsistent with traditional assumptions about the role of courts in a representative democracy. See, e.g., Posner, Legal Formalism, Legal Realism, and the Interpretation of Statutes and the Constitution, 37 CASE W. RES. L. REv. 179, 196-97 (1987).

8 These are the traditional "pluralist" assumptions of constitutional and statutory theory, as well as those of most Supreme Court decisions. For different assumptions of republicanism and communitarianism, see Michelman, The Supreme Court, 1985 Term-Foreword: Traces of Self-Government, 100 HARv. L. REv. 4 (1986) and M. SANDEL, Liberalism AND THE Limits of JUSTICE (1982), respectively. These political theories would be consonant with an even more dynamic, current policy approach to statutory interpretation. 
model's descriptive power is superior to that of the models traditionally invoked by the Court-intentionalism and the progressive modified intentionalism of Henry Hart's and Albert Sacks's legal process materials. ${ }^{9}$ I do not contend that the model here is always, or usually, easier to apply than the intentionalist or modified intentionalist approaches. I only contend that it explains the results of the Supreme Court's cases better and is a more candid analysis of what the Court does. Finally, the Article contrasts my dynamic interpretation model with the more ambitious approach posited by Professor Ronald Dworkin. Dworkin, too, argues for dynamic interpretation, in which statutes change as "law's integrity" develops and changes. My approach is more cautious and conventional than that of Dworkin. He envisions judges performing the truly herculean task of reading magisterial coherence into the law. ${ }^{10}$ I envision judges as diplomats, whose ordering authority is severely limited but who must often update their orders to meet changing circumstances.

\section{A MOdel of Dynamic Statutory Interpretation}

The static vision of statutory interpretation prescribed by traditional doctrine is strikingly outdated. In practice, it imposes unrealistic burdens on judges, asking them to extract textual meaning that makes sense in the present from historical materials whose sense is often impossible to recreate faithfully. As doctrine, it is intellectually antediluvian, in light of recent developments in the philosophy of interpretation. ${ }^{11}$ Interpretation is not static, but dynamic. Interpretation is not an archeological discovery, ${ }^{12}$ but a dialectical creation. Interpretation is not mere exegesis to pinpoint historical meaning, but hermeneutics to apply that meaning to current problems and circumstances.

- See H. HART \& A. SAcks, supra note 4, at 1287-1380.

10 See R. Dworkin, supra note 1, at 239; R. Dworkin, A Matter of PrinciPLE 316 (1985) [hereinafter A MATter of PRINCIPLE].

"For an introduction to recent developments in the philosophy of interpretation, see J. Guller, On Deconstruction: Theory and Criticism After Structuralism (1982); D. Hoy, The Critical Gircle: Literature, History, and Philosophical Hermeneutics (1982); F. Kermode, The ARt of Telling: EsSAYS ON Fiction (1983); J. WeinsheIMER, Gadamer's HermeneUtics: A Reading oF Truth and Method (1985). For syntheses of these developments presented for a legal audience, see Hoy, Interpreting the Law: Hermeneutical and Post-Structuralist Perspectives, 58 S. CAL. L. REv. 136 (1985); Poster, Interpreting Texts: Some New Directions, 58 S. Cal. L. Rev. 15 (1985).

12 Professor T. Alexander Aleinikoff suggested to me the idea that traditional statutory interpretation is like an archeological expedition. He compares the "archeological metaphor" with a "nautical metaphor," in which Congress turns the statute out to sea and leaves it to drift unpredictably. 
The dialectic of statutory interpretation is the process of understanding a text created in the past and applying it to a present problem. This process cannot be described simply as the recreation of past events and past expectations, for the "best" interpretation of a statute is typically the one that is most consonant with our current "web of beliefs" and policies surrounding the statute. ${ }^{13}$ That is, statutory interpretation involves the present-day interpreter's understanding and reconciliation of three different perspectives, no one of which will always control. These three perspectives relate to (1) the statutory text, which is the formal focus of interpretation and a constraint on the range of interpretive options available (textual perspective); (2) the original legislative expectations surrounding the statute's creation, including compromises reached (historical perspective); and (3) the subsequent evolution of the statute and its present context, especially the ways in which the societal and legal environment of the statute has materially changed over time (evolutive perspective).

Under dynamic statutory interpretation, the textual perspective is critical in many cases. The traditional understanding of the "rule of law" requires that statutes enacted by the majoritarian legislature be given effect, and that citizens have reasonable notice of the legal rules that govern their behavior. ${ }^{14}$ When the statutory text clearly answers the interpretive question, therefore, it normally will be the most important consideration. Exceptions, however, do exist because an apparently clear text can be rendered ambiguous by a demonstration of contrary legislative expectations or highly unreasonable consequences. ${ }^{16}$ The historical perspective is the next most important interpretive consideration; given the traditional assumptions that the legislature is the supreme lawmaking body in a democracy, the historical expectations of the en-

13 Cf. Farber \& Frickey, Practical Reason and the First Amendment, _ UCLA L. Rev. - (1987) (forthcoming) (similar approach to application of the First Amendment).

${ }^{14}$ Moore, A Natural Law Theory of Interpretation, 58 S. CAL. L. Rev. 277, 313-18 (1985), posits six "rule of law" values that should inform a natural law theory of interpretation. These are boiled down to the two mentioned in the text. They rest upon assumptions that might readily be questioned. See, e.g., Parker, The Past of Constitutional Theory-And Its Future, 42 OHo ST. L.J. 223, 249-56 (1981).

15 See, e.g., Church of the Holy Trinity v. United States, 143 U.S. 457 (1892) (interpreting relatively clear statutory prohibition leniently in light of legislative history and current policy); see also Midlantic Nat'l Bank v. New Jersey Dep't of Envtl. Protection, $106 \mathrm{~S}$. Ct. 755 (1986) (bankruptcy trustee not allowed to abandon property, although clearly allowed to do so by the Bankruptcy Code, when such abandonment threatens public health and safety); United States v. Brown, 333 U.S. 18, 25 (1948) (criminal statute should not be subject to the usual narrow construction, when to do so would "override common sense and evident statutory purpose"); Shine v. Shine, 802 F.2d 583 (1st Cir. 1986) (same); Posner, supra note 7, at 204-05 (analyzing and criticizing United States v. Locke, 471 U.S. 84 (1985)). 
acting legislature are entitled to deference. Hence, when a clear text and supportive legislative history suggest the same answer, they typically will control.

The dynamic model, however, views the evolutive perspective as most important when the statutory text is not clear and the original legislative expectations have been overtaken by subsequent changes in society and law. In such cases, the pull of text and history will be slight, and the interpreter will find current policies and societal conditions most important. The hardest cases, obviously, are those in which a clear text or strong historical evidence or both, are inconsistent with compelling current values and policies.

The remainder of this Part will illustrate how dynamic statutory interpretation works and will conclude with a cautious model of dynamic interpretation. Recent Supreme Court cases will be used to demonstrate the intuitive cogency of my multiple-perspective approach and to suggest instances where an originalist approach is not sensible. Indeed, the Court often manipulates originalist arguments to reach results that can better be supported by a dynamic view of the statute. The first example draws upon an old, generally phrased statute, for which a dynamic approach is strikingly different from the traditional approach. Consider the difficulty the Court had in squeezing a sensible result out of the traditional approach.

Section 1 of the Civil Rights Act of $1871,{ }^{16}$ codified at section 1983 of title forty-two of the U.S. Code, provides that persons who subject others to "the deprivation of any rights, privileges, or immunities secured by the Constitution and laws, shall be liable to the party injured in an action at law, suit in equity, or other proper proceeding for redress." 17 The Supreme Court, in Smith $v$. Wade, ${ }^{18}$ decided whether punitive damages could be recovered under section 1983 by a prison inmate who was injured after being placed in a cell with dangerous inmates, allegedly in reckless disregard of the plaintiff's safety. The Gourt held that punitive damages could be awarded in such a situation; ${ }^{19}$ the two dissenting opinions argued that punitive damages could only be awarded upon a showing that the defendant had acted with actual intent to injure the plaintiff prisoner. ${ }^{20}$ Neither the majority nor

1817 Stat. 13 (1871) (current version at 42 U.S.C. $\S 1983$ (1982)).

17 Id.

18461 U.S. 30 (1983).

10 Id. at 34-56.

${ }^{20}$ Justice Rehnquist, joined by Chief Justice Burger and Justice Powell, argued in the primary dissent that "a forthright inquiry into the intent of the 42d Congress and a balanced consideration of the public policies at issue compel the conclusion that the proper standard for an award of punitive damages under $\$ 1983$ requires at least 
the dissenting opinions found decisive support for their views in the generally worded text or in the legislative history of the statute.

Nonetheless, the basic clash between the majority opinion and the primary dissenting opinion in Smith $v$. Wade was argued in terms of the intent of Congress in 1871. Both opinions relied on the common law rules of punitive damages existing in 1871, assuming that most of the members of Congress were attorneys who would have expected that the common law would fill any gaps in the statute. ${ }^{21}$ The majority opinion cited dozens of nineteenth century state cases in which punitive damages were awarded and in which the state court suggested that "wanton" or "reckless" behavior could justify such damages. ${ }^{22}$ The primary dissenting opinion responded with dozens of nineteenth century state cases seeming to require "actual malice" or "spite" to justify punitive damages. ${ }^{23}$

While the Justices' excursions into these historical materials is interesting, they are of little relevance to the best interpretation of the statute. To begin with, the battle of the string citations is indeterminate because there are plenty of cases to support either point of view. Indeed, if the members of the forty-second Congress had been aware of the several hundred opinions cited by the Court and the primary dissent in Smith v. Wade, my guess is that they would have been confused and without any "intent" pertaining to this issue.

Furthermore, the analysis in both opinions appears basically ahistorical and result-oriented. The opinions misperceived the common law in 1871 by focusing on the defendant's state of mind. This is a focus that had crystallized by the end of the nineteenth century in tort law and criminal law. But in the third quarter of the century, tort theory was struggling with subtly different issues. For example, the debate in the 1850 s and 1860 s was whether punitive damages were allowable in

some degree of bad faith or improper motive on the part of the defendant." Id. at 56 (Rehnquist, J., dissenting). Justice O'Connor's dissent, while agreeing with Justice Rehnquist's conclusion, rejected his analysis. She argued that no clear congressional intent was discernible. Her disagreement with the majority opinion was based on her concern with the "special problems" of permitting awards of punitive damages for the recklessness of public officials. See id. at 94 (O'Connor, J., dissenting).

${ }^{21}$ See Briscoe v. LaHue, 460 U.S. 325, 330 (1983); City of Newport v. Fact Concerts, Inc., 453 U.S. 247, 258 (1981). While this maxim of interpretation is not a consistently reliable guide for divining "legislative intent," it may be particularly appropriate for construing $\S 1983$, because the statutory language explicitly refers the injured party to "an action at law" for damages or "a suit in equity" for injunctive relief and, hence, suggests a formal legislative reliance on existing common law or equitable remedies.

${ }^{22} \mathrm{See} 461$ U.S. at $35 \mathrm{nn} .3-4$ (punitive damages awarded generally), $39 \mathrm{n} .8$ (punitive damages awarded for wanton or reckless behavior), 45 n.12 (same).

${ }^{23}$ See id. at 60 n.3, 78 n.12 (Rehnquist, J., dissenting). 
tort cases at all. The majority rule by 1871 was that such damages were permissible if a defendant's conduct were especially outrageous. ${ }^{24}$ Thus, those jurisdictions allowing punitive damages justified the "extra" recovery mostly on the "oppressive" conduct of the defendant, rather than on the defendant's state of mind..$^{25}$

Finally, the historical analysis-to the extent it supports any interpretation of the statute-supports what is in my view the wrong interpretation. Under an "outrageous conduct" test the jailer's conduct in Smith $v$. Wade probably does not justify punitive damages. Indeed, a court in 1871 might not have considered the jailer's conduct to have been sufficiently outrageous to have justified even compensatory, let alone punitive, damages. ${ }^{26}$ Consequently, had the Supreme Court wanted to freeze the meaning of section 1983 at its time of origin, the result in Smith $v$. Wade would have been different.

A dynamic approach to section 1983 would not stop with the historical perspective, especially when the historical evidence is indirect and confusing and the statute is old. The interpreter would ask herself what interpretation is most consistent with section 1983 as it has evolved over time. Indeed, in Smith $v$. Wade Justice O'Connor refused to join either the primary dissenting opinion or the majority opinion, finding their discussions of history "unilluminating."27 Instead, she considered the current policy context of section 1983. All too briefly, she explained that two current policies conflicted: the policy to deter official wrongdoing versus the concern that overdeterrence would both chill officials from vigorous exercise of their discretionary responsibilities and overburden the courts. ${ }^{28}$ I applaud Justice O'Connor's skepticism about the usefulness of the historical perspective here and endorse her focus on the current mix of purposes in the statute. On the other 1876).

24 See 2 C. Addison, A Treatise on the Law of Torts $\S 1392$ (4th ed.

${ }_{25}$ See T. Sediwick, A Treatise on the Measure of Damages 523 (5th ed. 1869); see also 2 C. ADDISON, supra note 24 , at $\$ 1392$ (vindictive damages allowed when "the wrong or injury is of a grievous nature, done with a high hand, . . . or with words of contumely and abuse, and by circumstances of aggravation"); $2 \mathrm{~J}$. GREENLEAF, LAW OF EVIDENCE $§ 253$ (1876) (lengthy argument opposing punitive damages); F. Hilliard, LAw OF ReMEDIES FOR TORTS 441 (2d ed. 1867) (malice is generally required for exemplary damages in the states that recognize such damages).

${ }_{28}$ See, e.g., Moxley v. Roberts, 43 S.W. 482 (Ky. 1897) (jailer not liable for beating of one prisoner by another unless he actually knew of the beating and failed to stop it); Williams v. Adams, 85 Mass. (3 Allen) 171 (1861) (prisoner cannot sue jailer for failure to provide him with food, clothing, and warmth, absent a showing of actual malice or such gross negligence as would authorize a jury to infer malice).

27461 U.S. at 92 (O'Connor, J., dissenting).

${ }^{28}$ Id. at 93-94 (O'Connor, J., dissenting). The majority opinion favored the former policy while Justice O'Connor found the latter more weighty. 
hand, her dissenting opinion slights the rich interpretive history of section 1983 and ignores policy values that would support punitive damages when official conduct has recklessly imperiled constitutional rights.

I should go one step beyond Justice O'Connor's dissenting opinion and ask whether modern common law provides interpretive guidance. In fact, the opinion for the Court in Smith v. Wade fleetingly mentioned the current common law rule that reckless misconduct can justify punitive damages. ${ }^{29}$ This is the only persuasive authority invoked by the majority opinion, for the common law rule represents a well-considered modern consensus about when the imposition of punitive damages is appropriate. ${ }^{30}$ Reliance on evolving modern common law to fill in statutory gaps, moreover, is consistent with the methodology the Court has used in other cases interpreting section 1983. In fact, Professor Seth Kreimer has demonstrated that in determining remedies, immunities, and other issues under section 1983, the Court typically does not undertake "a search for century-old legislative intent or common law context"; instead it creates "a federal common law that the Court regards as appropriate to modern social and political realities."31 This fundamental point, that a federal common law approach is sensible, is supported not only by the general, non-confining language of section 1983, but also by the substantial changes in the societal and legal context of section 1983.

Section 1983 was a congressional response to state-sanctioned abuse of civil rights in the South during the Reconstruction. ${ }^{32}$ Its enactment aroused a flurry of activity, but it soon fell into disuse because it was narrowly interpreted to provide a remedy only when official action was sanctioned by state law. In Monroe $v . P a p e,{ }^{33}$ however, the Supreme Gourt interpreted section 1983 to provide a remedy for official actions not sanctioned by state law. This interpretation exemplified the Warren Gourt's commitment to civil rights cases in the 1950 's and (1979)).

29461 U.S. al 46-47 (quoting Restatement (SECOND) OF TORTS § 908(2)

so Modern law also supplies the majority's best response to the current policy argument asserted in Justice O'Connor's dissent. The Supreme Court held in Gertz v. Robert Welch, Inc., 418 U.S. 323, 349 (1974), that punitive damages could be asserted in defamation cases when there was proof of "knowledge of falsity or reckless disregard for the truth." The Court's concern in Gertz that punitive damages might chill the exercise of critical first amendment rights suggests that a more restrictive punitive damages rule would not be appropriate for $\S 1983$.

${ }^{31}$ Kreimer, The Source of Law in Civil Rights Actions: Some Old Light on Section 1983, 133 U. PA. L. REv. 601, 611 (1985).

${ }^{32}$ For an excellent historical discussion of the interpretation of $\$ 1983$, see Blackmun, Section 1983 and Federal Protection of Individual Rights-Will the Statute Remain Alive or Fade Away?, 60 N.Y.U. L. REv. 1 (1985).

s3 365 U.S. 167 (1961). 
1960 's. This commitment, of course, was not just to the civil rights of blacks in the South, but also to the rights of criminals, inmates of prisons and mental hospitals, and others.

The explosion of constitutional tort litigation that followed Monroe forced the Court to fill in the many gaps in section 1983: who can be sued, what remedies are available, which statute of limitations is applicable, and so forth. The modern common law of tort remedies and immunities is a convenient way to fill in these gaps. Moreover, it is a sensible way because it reflects the accumulated wisdom of incremental judicial doctrine-building in a related field. Yet, as Justice O'Connor's dissent in Smith $v$. Wade reminds us, the common law gap-filling rules should be modified when appropriate to fit the Court's ongoing policybalancing within the context of section 1983 litigation. Given the commitment in the last thirty years of the Court and our society to deter civil rights violations by officials, the common law punitive damages rule should not be relaxed in the context of section 1983.

Smith v. Wade is a particularly dramatic case calling for dynamic interpretation. The evolutive perspective is critical for two reasons. First, the language of the statute gives the Court a great deal of freedom in interpreting it; this makes the textual perspective of little importance. Second, the statute's interpretation and the needs and values of society have changed substantially since the enactment of the statute. These developments render the historical perspective less persuasive. Had the statute been recently enacted and filled with detailed policy prescriptions or expectations reflected in its legislative history, a dynamic interpretation would not differ much from originalist statutory interpretation. The language of the statute would answer most of the interpretive issues, and national policy values would have changed little, if at all. Nevertheless, some recent statutes have evolved so quickly that dynamic interpretation offers a richly different perspective from that of traditional theory. Consider the following case.

In United Steelworkers $v$. Weber, ${ }^{34}$ the Supreme Court addressed the question of whether Title VII of the Civil Rights Act of $1964^{35}$ permits employers and unions to adopt voluntary affirmative action plans. Brian Weber, a white employee, sued his union and employer for entering into a collective bargaining agreement that included an affirmative action plan to redress the underrepresentation of blacks in the employer's skilled workforce. The plan that Weber challenged reserved fifty percent of the spots in the company's craft-training program for

ss 78 Stat. 253 (1964) (current version at 42 U.S.C. $§ 2000$ e (1982)). 
blacks. Weber argued that this penalized whites and effectively "discriminated" against them on the basis of race, in violation of Title VII. A divided Court rejected Weber's interpretation. While the Court's decision is the proper one, the Court had great difficulty justifying its result under traditional theories of statutory interpretation.

The statutory text does not decisively answer the interpretive issue, contrary to labored readings by both the majority and dissenting opinions. $^{38}$ Section 703 (d) makes it an unlawful practice for an employer or labor organization "to discriminate against any individual because of his race, color, religion, sex, or national origin in admission to, or employment in, any program established to provide apprenticeship or other training."37 The operative word is "discriminate," which is not defined in the Act. Weber interpreted the antidiscrimination rule of section 703(d) to prevent any and every differential treatment of employees on racial grounds. This interpretation is plausible. It is also plausible to interpret the antidiscrimination rule to penalize only discrimination which is invidious, for the term "discrimination" in common usage means something more than just different treatment. ${ }^{38}$

Other provisions of Title VII might shed some light on the meaning of "discrimination," of course. Thus, section 703(h) provides that an employer can apply "different terms, conditions, or privileges of employment pursuant to a bona fide seniority or merit system . . provided that such differences are not the result of an intention to discriminate because of race." 39 This supports Weber's interpretation; if section 703(d) only prevented invidious discrimination, there would be no need for a seniority defense, and the italicized proviso would be un-

s6 See 443 U.S. at 204-06 (majority opinion), 220-222 (Rehnquist, J., dissenting).

st 78 Stat. 255-56 (1964) (current version at 42 U.S.C. \& 2000e-2(d) (1982)). Section $703(a)(1)$ makes it an unlawful practice for an employer or labor organization "to discriminate against any individual with respect to his compensation, terms, conditions, or privileges of employment, because of such individual's race, color, religion, sex, or national origin." Id. (current version at 42 U.S.C. § 2000e-2(a)(1) (1982)).

38 Thus I reject the dissenting opinion's strong objection that Congress would have been "hard pressed" to have chosen language more clearly protecting Weber than that of $\$ 703$ (d). See 443 U.S. at 226 (Rehnquist, J., dissenting). For instance, if Congress really wanted a sweeping protection against any and all differential treatment, it might have made any failure by the employer to include any individual in any program established to provide apprenticeship or other training as a result of prohibited criteria, namely race, an unlawful employment practice.

s9 78 Stat. 257 (1964) (current version at 42 U.S.C. $\$ 2000 \mathrm{e}-2(\mathrm{~h})(1982)$ ) (emphasis added); see also $\S 703(\mathrm{e})(1), 78$ Stat. 256 (1964) (current version at 42 U.S.C. $\S 2000 \mathrm{e}-2(\mathrm{e})(1)(1982)$ ) (an employer may hire individuals, an employment agency or labor organization may classify or refer individuals, and an employment agency or labor organization or labor-management committee may admit individuals to training programs, on the basis of religion, sex, or national origin-but not race-if the basis is a "bona fide occupational qualification"). 
necessary. On the other hand, Title VII also addresses the affirmative action issue in specific terms. Section 703(j) provides that the Act does not "require any employer . . . to grant preferential treatment to any individual or to any group because of the race" of that individual or group. ${ }^{40}$ That the provision does not say "permit or require . . . preferential treatment" lends some support to the union's interpretation of Title VII. ${ }^{41}$

On the whole, I consider the textual arguments inconclusive; good arguments can be made for either position. Title VII was obviously not drafted with a coherent vision of discrimination in mind, ${ }^{42}$ and the fact remains that the statutory text never defines "discriminate." The historical perspective provides some, but not decisive, guidance for solving the interpretive puzzle. There was a great deal of discussion of "quotas" in the legislative debates; supporters of the civil rights bill repeatedly assured opponents and undecided legislators that the statute would not mandate racial quotas. The dissenting opinion in Weber meticulously recounted these debates and argued that the statutory "deal" was that there would be no mandatory or voluntary quotas. ${ }^{43}$ This is far

4078 Stat. 257 (1964) (current version at 42 U.S.C. $\S 2000 \mathrm{e}-2(\mathrm{j})(1982)$ ) (emphasis added).

41 The Court's opinion treats this argument as a decisive textual response to the dissenting opinion's textual analysis. See 443 U.S. at 204-08. I do not consider the argument at all decisive, for it rests upon the highly unreliable maxim of statutory construction "inclusio unius est exclusio alterius" (inclusion of one means exclusion of the other). See, e.g., Herman \& MacLean v. Huddleston, 459 U.S. 375, 387 n.23 (1983) (rejecting application of the expressio unius maxim because such a presumption would undermine the purpose of the 1933 Securities Act); National Petroleum Refiners Ass'n v. FTC, 482 F.2d 672, 676 (D.C. Cir. 1973) (stating that the "[expressio unius] maxim is increasingly considered unreliable"); $c f$. Hishon v. King \& Spalding, 467 U.S. 69, 78 \& n.11 (1984) (applying the expressio unius theory only where the Court found a detailed, carefully considered list of exemptions, from which one item was notably absent). It is also an implausible view of $\S 703(j)$, which was added to attract conservative support for the civil rights bill in the Senate. See 110 Cong. REC. 1268812691 (1964) (Sen. Saltonstall). The conservatives, such as Senator Dirksen, did not want to broaden the civil rights bill at all; $\S 703(j)$ was a narrowing provision, if anything.

12 Indeed, Title VII went through many different stages. President Kennedy's initial job discrimination provision was weak. The House subcommittee strengthened it with a broad mandate against discrimination based on race, religion, and national origin. See C. Whalen \& B. Whalen, The Longest Debate 37-38 (1985). It provided for enforcement by the Equal Employment Opportunity Commission (EEOC). The full House Judiciary Committee weakened the job discrimination title by curtailing the powers of the EEOC, but retained the forceful prohibition against "discrimination" on the basis of race, religion, and national origin. See id. at 57-58. The full House amended $\S 703(\mathrm{a})(1)$, (d) to prohibit sex discrimination-obviously a very different type of problem from race discrimination. The Senate added $\S 703(\mathrm{~h})$, (j). To expect textual coherence from such piecemeal drafting is probably too much to demand of the legislative process.

43443 U.S. at 231-53 (Rehnquist, J., dissenting). Ronald Dworkin has cogently 
from clear, however, because nowhere in the legislative history does any member of Congress explicitly state opposition to both voluntary and mandatory affirmative action programs. This is not surprising, as the debates focused on government-compelled quotas. The Weber situation was not discussed on the public record and most likely was not anticipated.

The majority opinion largely ignored the intentionalist evidence assembled by the dissenting opinion and countered with a modified intentionalist argument: the purpose of Title VII, set forth in the House Judiciary Committee report, was to obtain more jobs for blacks. ${ }^{44}$ That purpose was thwarted in the 1970's by the continued effects of past discrimination. To fulfill this statutory purpose, the Court reasoned it should broadly validate voluntary affirmative action programs such as the plan in Weber. This argument, however, subordinates one purpose of Title VII-obtaining more jobs for blacks-to another-creation of a color-blind society. ${ }^{45}$ Two central purposes of the statute conflict in the Weber case, and the Court offered no persuasive justification to prefer its purpose over the competing one.

While there is much more evidence relating to the historical perspective in Weber than there is in Smith $v$. Wade, the evidence points in many different directions. In my opinion, the historical perspective tilts toward Weber's interpretation, because the legislative history reveals hostility to quotas generally and because the purpose most broadly accepted in Congress was that of creating a color-blind society. ${ }^{6}$ Hence, if I limited my consideration to the textual and historical

criticized Justice Rehnquist's use of legislative history in A MatTER OF PRINCIPLE, supra note 10 , at $316,324-26$.

14 See 433 U.S. at 201-04 (summarizing evidence of that congressional purpose, and citing language from the House Report, H.R. REP. No. 914, 88th Cong., 1st Sess., pt. 1 , at 18 (1963)).

15 See 443 U.S. at 254-55 (Rehnquist, J., dissenting); A MATter OF Principle, supra note 10 , at $328-29$.

48 I find two things critical. The Civil Rights Act barely beat back the Southern Democratic filibuster in the Senate (by a vote of 71 to 29 , four votes more than the required two-thirds majority), and only with the support of Senator Dirksen and about a dozen other Republican conservatives. See C. WHALEN \& B. WhaleN, supra note 42, at 164-99; Vaas, Title VII: Legislative History, 7 B.C. InDUS. \& CoM. REv. 431, 446 (1966). It is inconceivable to me that these Senators, as well as some of the Democrats voting to invoke cloture, would have favored a bill that permitted, and even encouraged, voluntary affirmative action plans. With regard to the legislative purpose, the theme that dominated the debates was equality of opportunity and the creation of a color-blind society. The only purpose for which there was substantial congressional consensus was the creation of a color-blind society. See also Meltzer, The Weber Case: The Judicial Abrogation of the Antidiscrimination Standard in Employment, $47 \mathrm{U}$. ChI. L. Rev. 423, 456 (1980) (the Court's opinion "change[d]" the statute, undoing "the roots of the bargain struck by the 88th Congress"). 
evidence in Weber, I should interpret Title VII to prohibit voluntary affirmative action: the textual perspective is inconclusive, and the historical perspective tilts toward Weber's position.

Nevertheless, I agree with the Weber Court's result because of the evolutive perspective. The separate concurring opinion of Justice Blackmun is the most sensible opinion in the Weber case. Justice Blackmun argued that the evolution of Title VII created a practical dilemma for unions and employers that justified voluntary affirmative action in many cases. ${ }^{47}$ My dynamic interpretation of Title VII would start with this insight and broaden it to include our changing concept of discrimination. An assumption of most supporters of Title VII in 1964 was that equality of opportunity for minorities would in due time yield equality of result in employment. As the statute was implemented by the courts and the Equal Employment Opportunity Commission (EEOC), however, it became apparent that formally equal opportunities were not always leading to significantly greater representation of minorities in the workforce. ${ }^{48}$ American society came to understand that the invidious effects of discrimination might last long after the discrimination itself ceased and that more affirmative measures were needed to afford any reasonable chance for a color-blind society in the future. ${ }^{40}$ Consequently, there was greater pressure on employers and unions to undertake voluntary efforts to re-evaluate their employment practices; the Supreme Court strongly encouraged such voluntary efforts in the 1970's. ${ }^{.0}$

Once the most blatant forms of discrimination were eliminated, the EEOC and other enforcers sought to eliminate more subtle forms of discrimination, such as facially neutral job classifications which had the effect of excluding minorities. The Supreme Court in Griggs v. Duke

47443 U.S. at 209-16 (Blackmun, J., concurring). Justice Blackmun's concurrence is largely drawn from the opinion of Judge Wisdom, who dissented from the court of appeals decision reversed by the Weber Court, 563 F.2d 216, 227 (5th Cir. 1977) (Wisdom, J., dissenting).

18 The facts of Weber illustrate this problem. Even though the employer claimed it did not discriminate against blacks, the craft workforce remained only $1.83 \%$ black into the 1970's, in large part because one qualification for becoming a craft worker was prior experience, which blacks did not have, arguably due to past discrimination. See 443 U.S. at 197-99.

${ }^{19}$ Cf. University of California Regents v. Bakke, 438 U.S. 265 (1978) (majority of the Court approved state affirmative action but not quotas).

so See Franks v. Bowman Transp. Co., 424 U.S. 747, 778-79 (1976) (noting that employers may retroactively alter seniority plans to ameliorate the effects of past discrimination); Alexander v. Gardner-Denver Co., 415 U.S. 36, 44 (1974) ("Congress ... provide[d] . . . the [EEOC] $\ldots$ authority ... to promote voluntary compliance with the requirements of Title VII."). For a recent example of the Court's commitment to this value, see Firefighters v. Cleveland, 106 S.Ct. 3063, 3072 (1986). 
Power Co. ${ }^{81}$ held that a job qualification test that was not demonstrably discriminatory in purpose nonetheless would violate Title VII if it had the effect of excluding a group on the basis of race. This decision underscored the idea that results matter ${ }^{\mathbf{5 2}}$ but also generated a practical dilemma for companies seeking to comply with Title VII. Even if they were not treating blacks and other minorities differently from white males, companies and unions-like those in Weber-faced potential Title VII liability if the numbers of blacks and other minorities in their workforce remained too low. Given the Supreme Court's endorsement of voluntary programs, the natural response was voluntary affirmative action programs such as the one in Weber.

This dynamic approach to the Weber problem is particularly persuasive because it recognizes not only that the very nature of the problem had changed since 1964, but also that the legal and societal context of Title VII had changed. In 1964, the legal culture-legislators, judges, administrators, and commentators-focused on how to root out discrimination inspired by racial animus. People thought that rooting out actual prejudice would create a color-blind society. The intellectual focus changed over the next fifteen years, as the legal community came to realize that discrimination could be just as invidious even when it could not be established that prejudice was at its root. The concept of the continuing effects of historical patterns of discrimination suggested that current institutions might perpetuate discrimination even though no one in those institutions remained personally prejudiced. This insight was not a historical concern of the 1964 Act, but it evolved into a current concern and was recognized in subsequent statutes, judicial decisions, and commentary. ${ }^{\text {ss }}$

Indeed, the legal culture's rethinking of the concept of discrimination has entailed a more positive vision, in which voluntary affirmative

s1 401 U.S. 424 (1971).

82 Although the Griggs Court reaffirmed the color-blind purpose of Title VII, the rationale for the decision was a shift of emphasis: "The Act proscribes not only overt discrimination but also practices that are fair in form, but discriminatory in operation ... . Congress directed the thrust of the Act to the consequences of employment practices, not simply the motivation." Id. at 431-32.

os See, e.g., Voting Rights Act Amendments of 1982, Pub. L. No. 97-205, 96 Stat. 134 (codified at 42 U.S.C. $\$ 1973$ (1982)) (a voting qualification or prerequisite may be illegal if it has the practical effect of narrowing political participation of protected minorities); Alexander v. Choate, 469 U.S. 287, 292-97 \& n.11 (1985) (interpreting Rehabilitation Act \& 504; anti-discrimination law since 1973 has increasingly focused on getting results for historically disadvantaged minorities); Lau v. Nichols, 414 U.S. 563 (1974) (expansive interpretation of Title VII of the Civil Rights Act to achieve results for language minorities); Fiss, The Fate of an Idea Whose Time Has Come: Anti-Discrimination Law in the Second Decade after Brown v. Board of Education, 41 U. Chi. L. Rev. 742, 764-70 (1974). 
action plays a critical role. Employers may desire to implement affirmative action for reasons unrelated to their own past discrimination-including a desire to promote workplace or societal diversity as a positive good or to improve service or to appeal to minority communities. ${ }^{54}$ Weber subserves this positive vision as well, and in the 1986 Term the Court applied Weber expansively to permit forward-looking affirmative preferences for women as well as racial minorities. ${ }^{.5}$ Justice Stevens (concurring in each case) suggested that the Court's decisions could not be justified by reference to Congress's historical intent or purpose in enacting Title VII but that the results were still justified by the evolution of the statute and Weber. ${ }^{\text {sB }}$

Weber suggests a lesson: when societal conditions change in ways not anticipated by Congress and, especially, when the legal and constitutional context of the statute decisively shifts as well, this current perspective should, and will, affect the statute's interpretation, notwithstanding contrary inferences from the historical evidence. The harder question is whether the evolutive perspective should be similarly persuasive in the face of more determinate statutory language. This problem poses the possible clash between the "rule of law" values of the textual perspective and the justice values of the evolutive perspective. Consider in this regard Firefighters Local Union No. 1784 v. Stotts, ${ }^{57}$ the next important interpretation of Title VII by the Supreme Court.

In Stotts a black firefighting captain in Memphis brought a Title VII class action against the City's Fire Department. The case was settled with the entry of a consent decree in 1980, which agreed to quotas for hiring and promoting blacks over a period of time. When, in 1981, the City was forced by budgetary concerns to lay off firefighters, the district court modified the consent decree to enjoin the layoff of black employees-who tended to be recent hires-thereby bumping some more senior white employees. The Sixth Circuit affirmed this modification, ${ }^{88}$ but the Supreme Court reversed, based upon two provisions of Title VII. The Court relied primarily on section $703(\mathrm{~h})$, which makes it lawful "for an employer to apply different standards of compensa-

st See Sullivan, The Supreme Court-Comment, Sins of Discrimination: Last Term's Affirmative Action Cases, 100 HARv. L. Rev. 78, 96 (1986).

ss See Johnson v. Transportation Agency, Santa Clara County, California, 107 S. Ct. 1442 (1987) (approving affirmative action plan for hiring women); California Fed. Sav. \& Loan Ass'n v. Guerra, 107 S. Ct. 683 (1987) (Title VII permits state law assuring extra pregnancy benefits).

so See Johnson, 107 S. Ct. at 1457-60 (Stevens, J., concurring); Guerra, 107 S.

Ct. at 695-97 (Stevens, J., concurring in part and concurring in the judgment).

${ }_{87} 467$ U.S. 561 (1984).

561 (1984).

${ }^{88}$ Memphis Fire Dep't v. Stotts, 679 F.2d 541 (6th Cir. 1982), rev'd, 467 U.S. 
tion, or different terms, conditions, or privileges of employment pursuant to a bona fide seniority or merit system." determinate. It appears to protect good faith seniority arrangements against disruption pursuant to Title VII. Any doubt about its meaning is erased by the legislative history, which indicates that the provision was put in the statute to protect workers' seniority rights against courtordered remedies. ${ }^{60}$ Although it detracts from the overall thrust of the statute, both in 1964 and thereafter, section 703(h) was part of a legislative compromise which protected the expectations of workers. Under conventional assumptions, courts are supposed to enforce such policy choices when they are clearly made by the legislature after a deliberative process. Hence, the evolutive perspective must yield where the text and evidence of legislative expectations support another interpretation.

As an alternative basis for its holding, the Stotts Court also relied on section $706(\mathrm{~g})$, which authorizes injunctions against discriminatory practices and "such affirmative action as may be appropriate," including reinstatement, hiring, back pay, "or any other equitable relief as the court deems appropriate." The last sentence of section 706(g) provides that reinstatement and other "make whole" remedies are not available to individuals suffering injury "for any reason other than discrimination" in violation of Title VII. ${ }^{61}$ The Stotts Court interpreted section $706(\mathrm{~g})$ to deny court-ordered affirmative action relief, based largely upon the statements in the legislative history that Title VII would not authorize court-ordered quotas. ${ }^{62}$ The Court's interpretation is defensible under the historical perspective for the same reasons the Weber dissent is. But it is not compelled, or even much supported, by the text of the statute: "individual relief suits" under Title VII can seek only "make whole" relief for victims of discrimination. A fair implication from the text is that "class action lawsuits" such as the one in Stotts may seek race-conscious affirmative relief, for that may be the most "appropriate" remedy. ${ }^{63}$ Indeed, the broad language "any other equitable relief as the court deems appropriate" was added by Congress to section $706(\mathrm{~g})$ in 1972 after careful deliberation over, and rejection of, Southern objections that courts had gone too far in ordering affirmative action relief under Title VII. ${ }^{64}$ Hence, the Gourt's reliance on sec-

s9 42 U.S.C. $\S 2000 \mathrm{e}-2(\mathrm{~h})$ (1982).

${ }^{60}$ For surveys of the legislative history of $\S 703(\mathrm{~h})$, see American Tobacco Co. v. Patterson, 456 U.S. 63, 71-75 (1982); International Bhd. of Teamsters v. United States, 431 U.S. 324, 350-52 (1977).

B1 42 U.S.C. $\S 2000 \mathrm{e}-5(\mathrm{~g})(1982)$.

${ }^{62}$ Stotts, 467 U.S. at 580-83.

63 See id. at 612 (Blackmun, J., dissenting).

Bt While considering the Equal Employment Opportunity Act of 1972, Pub. L. 
tion 706(g) is undermined by the same precept that supported its reliance on section 703(h): respect for legislative compromises. Even if the historical record were less clear, the position of the Stotts dissenters that section $706(\mathrm{~g})$ allows flexible judicial relief is compellingly supported by the evolution of Title VII and the changed circumstances outlined above. ${ }^{65}$

The three perspectives implicated in dynamic interpretation illustrated by these cases suggest a continuum. In many cases, the text of the statute will provide determinate answers, though we should trust our reading of the text primarily when the statute is recent and the context of enactment represents considered legislative deliberation and decision on the interpretive issue. This is one end of the continuum: the text controls. At the opposite end of the continuum are those cases where neither the text nor the historical context of the statute clearly resolves the interpretive question, and the societal and legal context of the statute has changed materially. In those cases, the evolutive context controls. In general, the more detailed the text is, the greater weight the interpreter will give to textual considerations; the more recent the statute and the clearer the legislative expectations, the greater weight the interpreter will give to historical considerations; the more striking the changes in circumstances (changes in public values count more than factual changes in society), the greater weight the interpreter will give to evolutive considerations. The following model very roughly reflects this continuum.

No. $92-261, \S 706,86$ Stat. 103 , the Senate rejected an amendment by Senator Ervin to prohibit government requirements of hiring goals or quotas. Senator Javits defended the existing judicial and executive policy of flexible relief, including hiring goals. See Stotts, 467 U.S. at 619-20 (Blackmun, J., dissenting).

es 467 U.S. at 610-20 (Blackmun, J., dissenting); see id. at 612 \& n.10 (as of 1984 , all of the courts of appeals had construed $\S 706(\mathrm{~g})$ broadly); Rutherglen, Procedures and Preferences: Remedies for Employment Discrimination, 5 REV. LITIGATION $73,79-82,120-21$ (1986) (courts have appropriately construed Stotts narrowly and continue to interpret $\$ 706(\mathrm{~g})$ broadly). Recent Supreme Court interpretations of Title VII suggest the viability of Weber and the narrow scope of Stotts. See Local 28 of the Sheet Metal Workers Int'l Ass'n v. EEOG, 106 S. Ct. 3019, 3034 (1986) (plurality opinion of Brennan, J., joined by Marshall, Blackmun \& Stevens, JJ.) (rejecting narrow view of $\$ 706(\mathrm{~g})$ ); id. at 3054 (Powell, J., concurring) (intermediate view of $\S 706(\mathrm{~g}))$. 
A Model for Reading Statutes Dynamically

Recent text specifically addressing the issue

Older text specifically addressing the issue

Recent text not specifically addressing the issue

Older text not specifically addressing the issue
Decisive Shift in Societal/Policy Gontext

Textual perspective controls, unless historical perspective indicates Congress did not consider the issue and policy consequences of following text would be absurd (Stotts)

Textual perspective usually controls, but evolutive perspective should be considered if historical perspective does not lend support to textual answer

Evolutive and historical perspectives are both relevant; former will control if historical evidence is ambiguous (Weber)

Evolutive perspective controls (Smith v. Wade)
Decisive Shift in Public Values

Textual perspective controls, unless historical perspective indicates Congress did not consider the issue or unless textual answer poses constitutional problems Text may be displaced if constitutional concerns are great
Evolutive perspective usually controls, unless there is strong historical evidence to the contrary (Weber)

Evolutive perspective controls

\section{Justification for Reading Statutes Dynamically}

My central proposition is that statutory interpretation is influenced by the ongoing, not just original, history of the statute. There are three types of arguments that have been advanced in favor of a static view of statutory interpretation. All three arguments ultimately appeal to the Constitution's concept of separate powers. The formalist argument is that the creation of law by federal judges is beyond the authority given them in the Constitution, for it trenches upon the lawmaking power given to Congress. The economic argument is that statutes are essentially contracts between interest groups and legislators, with fed- 
eral judges being no more than agents to enforce those contracts strictly. The traditional legal process argument is that such judicial lawmaking is "countermajoritarian" and so ought to be avoided in a democracy, where important policy decisions ought to be made by the majoritarian branches of government.

I shall articulate and respond to each of these arguments in turn, but there are certain themes which run through all my responses. One theme is a Madisonian view of the Constitution. Historical scholarship suggests that our constitutional system of government was not meant to be one of rigid separation of powers or pure majoritarianism. ${ }^{66}$ Instead, the polity created by the Constitution requires a government that is deliberative and promotes the common good, at least on important matters. Judicial lawmaking from statutes has a constructive role to play in such a polity, especially in light of the tendency of the legislature to produce too little up-to-date public-seeking policy and not to produce well-integrated policies. The vision of a tripartite government and the legitimacy of the system are not served by a straitjacketed theory of statutory interpretation but are better served by a flexible approach that is sensitive to current policy concerns. The final theme is jurisprudential. Interpretation is no longer automatically seen as an objective and mechanical process of "discovering" historical meaning; instead, the emerging view among historians, literary theorists, and legal scholars is that interpretation itself inevitably involves the "creation" of meaning from the interaction of the text, historical context, and evolutive context. ${ }^{67}$

\section{A. The Formalist Argument}

When the Supreme Court interprets statutes, it often invokes a strict formalist-sounding separation of responsibilities among the three branches of government, with the role of courts merely being to discern and apply the "intent" of the legislature. Professor Thomas Merrill has recently synthesized the Supreme Court's ad hoc approach and has presented a more systematic formal defense of intentionalist statutory interpretation. ${ }^{68}$ In brief, his argument is that the Constitution's sepa-

(6) This interpretation of Madison's view of the Constitution is discussed in D. Epstein, Thf Political Theory of The Federalist 145-46 (1984); see also Sunstein, Madison and Constitutional Equality, 9 HARv. J.L. \& PuB. PoL'y 11, 13-15 (1986).

67 See R. Dworkin, supra note 1, at 45-86 (discussing law as interpretation); $\mathrm{H}$. Gadamer, Truth and Method 292-95 (G. Barden \& J. Cumming trans. 1975) (arguing for the application of an evolutive concept of legal interpretation); see also infra notes 121-27 and accompanying text.

${ }^{68}$ Merrill, The Common Law Powers of Federal Courts, 52 U. GHI. L. REv. 1 
ration of powers gives all lawmaking power to Congress and none to the federal courts and that intentionalism is the only mode of statutory interpretation that is consonant with this constitutional division of functions. ${ }^{69}$

This is an unusually strong statement of the formalist argument, because it denies courts any lawmaking functions. Indeed, the most striking thing about the argument is how little support it derives from the text and structure of the United States Constitution. Nowhere does the Constitution say that Congress shall have all lawmaking power. It only says, in article I, that "[a]ll legislative Powers" shall be vested in Congress and, in article III, that the "judicial Power of the United States" shall be vested in the Supreme Court and whatever inferior courts Congress might create. ${ }^{70}$ The commonly accepted meaning of "legislative Powers"-in 1789 as well as today-is the power to enact statutes, which can override the common law that is part of the "judicial Power."'71

The specification in article III, section 2 of what the "judicial Power" might encompass supports the view that the Framers assumed federal courts would have common law-making powers. The first paragraph of section two lists nine areas of federal jurisdiction, and only one of those areas of potential federal jurisdiction, "Cases, in Law and Equity, arising under this Constitution, the Laws of the United States, and Treaties," explicitly contemplates that federal statutes would define the substantive rights of the parties. ${ }^{72}$ The Supreme Court was vested with original jurisdiction over two of these categories, that is, "Cases affecting Ambassadors, other public Ministers and Consuls, and those in which a State shall be a Party,"73 with the implicit power to make law to resolve these disputes. In practice the Court in its original jurisdiction cases has deferred to relevant federal-statutes but has often cre-

(1985).

${ }^{68}$ Id. at $3,19,32-33$.

${ }^{70}$ U.S. Const, arts. I, $\S 1$, III, $\S 2$ (emphasis added).

71 Black's LaW Dictionary 809-10 (5th ed. 1979); see 1 W. Blackstone, Commentaries on the Laws of England 63-70, 85-88, 91-92 (1765).

72 U.S. Const. art. III, $\S 2$, cl. 1 (emphasis added). Of course, even under this first head of federal jurisdiction, there is federal common law, at least for "Cases . . . arising under this Constitution." See Marbury v. Madison, 5 U.S. (1 Cranch) 137, 178 (1803). And the Supreme Court in this century has occasionally created federal common law from bare jurisdictional grants. See Textile Workers Union v. Lincoln Mills, 353 U.S. 448, 456-58 (1957) (jurisdiction granted to the Court by NLRA justifies creation of federal common law of labor relations); In re Debs, 158 U.S. 564, 599 (1894) (federal common law power under the commerce clause to abate interstate transportation nuisances).

${ }^{73}$ U.S. CoNST. art. III, $\S 2$, cl. 2. 
ated federal common law. ${ }^{74}$

Several of the areas of federal jurisdiction over which the Supreme Court has appellate jurisdiction similarly contemplate the creation of federal common law. For example, "Cases of admiralty and maritime Jurisdiction"75 had traditionally been governed by English judge-made law before American independence, and there is no reason to believe that the Framers intended to reject the traditional approach. ${ }^{76}$ "Controversies to which the United States shall be a Party" 77 might involve federal statutory law, but it is unlikely that the Framers expected Congress to regulate all aspects of federal government affairs, such as government contracting. ${ }^{78}$ Even "Controversies . . . between Citizens of different States" 78 were considered to be appropriate occasions for federal judicial lawmaking in the nineteenth century. ${ }^{80}$

Merrill disapproves of much of this lawmaking by federal courts or explains it away as "preemptive," 81 but the fact remains that the structure of the Constitution, the apparent expectations of the Framers, and two hundred years of Supreme Court practice establish the authority of federal courts to make law, subject to legislative override. ${ }^{\mathbf{8 2}}$ Nor does this undercut the constitutional precept of "separation of powers." The Framers' conception of separation of powers was inspired in large

74 See, e.g., United States v. Maine, 106 S. Ct. 951 (1986) (interpreting the doctrine of "ancient title"). In one celebrated line of cases, Illinois v. Gity of Milwaukee, 406 U.S. 91, 99-100, 104 (1972); Missouri v. Illinois, 200 U.S. 496 (1906), the Court created a federal common law of interstate water use. Congress enacted a comprehensive statutory regulation of this subject in 1972, and since then the Court has pulled back its common law. See International Paper Co. v. Ouellette, 107 S. Ct. 805, 810 (1987); City of Milwaukee v. Illinois, 451 U.S. 304, 317-19 (1981).

${ }_{76}$ U.S. ConsT. art. III, $\S 2$, cl. 2.

${ }^{78}$ While there have been federal statutes governing some admiralty issues, this remains a lively common law arena for the Court. See, e.g., American Export Lines, Inc. v. Alvez, 446 U.S. 274, 275-76 (1980); Moragne v. States Marine Lines, Inc., 398 U.S. $375,393-402$ (1970).

77 U.S. Const. art. III, $\S 2$, cl. 1.

${ }^{28}$ See, e.g., Clearfield Trust Co. v. United States, 318 U.S. 363, 367 (1943) (using federal common law to govern contract disputes involving the United States).

zo U.S. Const. art. III, \& 2, cl. 1.

${ }^{80}$ Swift v. Tyson, 41 U.S. (16 Pet.) 1, 18-19 (1842) (creating federal common law of commercial transactions in diversity suits), overruled, Erie R.R. v. Tompkins, 304 U.S. 64, 178-79 (1938). Although Swift's demise has reduced federal common lawmaking in diversity cases, it has not eliminated it. See, e.g., Banco Nacional de Cuba v. Sabbatino, 376 U.S. 398, 424-25 (1964) (applying the act of state doctrine to override state law in a diversity case and to preclude inquiry into the public acts that a foreign country committed within its territory).

${ }_{81}^{81}$ See Merrill, supra note 68, at 38, 40-41.

${ }^{82}$ For a sampling of the majority view that judges inherently have lawmaking powers, see, e.g., Traynor, Quo Vadis, Prospective Overruling: A Question of Judicial Responsibility, 28 HASTINGS L.J. 533, 535-36 \& n.7 (1977) (citing Lord Reid, The Judge as Lawmaker, 12 J. Soc'y PuB. Teachers L. (n.s.) 22 (1972)); White, The Working Life of the Marshall Court, 1815-1835, 70 VA. L. REv. 1, 49-50 (1984). 
part by Montesquieu's $D e L^{\prime} E s p r i t$ des Lois and is best explained in The Federalist. ${ }^{\mathbf{3}}$ Montesquieu had argued that tyranny was certain when the legislative, executive, and judicial powers were all combined in one authority, and the main purpose of separate powers in the Constitution was to protect against this certain abuse of federal power. ${ }^{84}$ Madison, echoing Montesquieu, argued in The Federalist that only "where the whole power of one department is exercised by the same hands which possess the whole power of another department, the fundamental principles of a free constitution are subverted."85 Thus, branches that are separate can still have some "partial agency in" or "control over" one another, and Madison saw the nature of those powers as mutually encroaching. ${ }^{8 B}$ In short, the Framers contemplated the existence of shared, rather than concentrated, lawmaking. Indeed, they paid little attention to judicial encroachment on legislative power generally, because "the judiciary, from the nature of its functions, will always be the least dangerous to the political rights of the Constitution; because it will be least in a capacity to annoy or injure them."87

For these reasons, Merrill's articulation of the formalist argument for intentionalist statutory interpretation is not persuasive. The formalist argument, however, does not have to deny federal courts all lawmaking powers. A weaker statement of the formalist argument would simply posit that the Framers and their contemporaries generally agreed that when a statute, not the common law, is at issue, the "judicial Power" is limited to "giving effect to the will of the Legislature."88 I believe this to be a more persuasive version of the formalist argument, but it only supports the proposition that the federal courts must respect statutory language, not the broader proposition that the courts must always replicate the original intent, or purpose, of the legislature. My response to this weaker version of the formalist argument rests upon historical, comparative, and jurisprudential analysis.

8s See D. EPSTEIN, supra note 66, at 127-33.

84 See C. Montesquieu, The Spirit of The Laws, Book XI, ch. VI (1765), quoted in The Federalist No. 47, at 302 (J. Madison) (C. Rossiter ed. 1961).

83 The Federalist No. 47, at 302-03 (J. Madison) (C. Rossiter ed. 1961).

${ }^{86}$ Id. at 302; see D. Epstein, supra note 66, at 130-31.

87 The Federalist No. 78, at 465 (A. Hamilton) (C. Rossiter ed. 1961). The reason for the relative powerlessness of the judiciary, explained Hamilton, is that, unlike the legislature, the judiciary has no taxing or spending power and, unlike the executive, the judiciary has no independent enforcement power. Id.

${ }^{88}$ Osborn v. Bank of the United States, 22 U.S. (9 Wheat.) 738, 866 (1824); see The Federalist No. 78, at 469 (A. Hamilton) (C. Rossiter ed. 1961) ("The courts must declare the sense of the law; and if they should be disposed to exercise WILL instead of JUDGMENT, the consequence would equally be the substitution of their pleasure to that of the legislative body."). 


\section{The Historical Response}

The irony of modern formalism is that in limiting statutory interpretation to seeking out original legislative intent, it substitutes late nineteenth century assumptions for those that the Framers would have intended to guide the "judicial Power." Intentionalist statutory interpretation is probably not what the Framers had in mind when they defined the "judicial Power" in article III. ${ }^{89}$ Educated lawyers in 1789 would have considered statutory texts binding on courts, but would not have dogmatically argued that statutory interpretation involves nothing more than divining the intent of the legislature. The evidence suggests, moreover, that the Framers were no more intentionalist than their contemporaries.

Sir William Blackstone's Commentaries describe judges as "depositories of the law," whose job is to "determine not according to his private judgment, but according to the known laws and customs of the land; not delegated to pronounce a new law, but to maintain and expound the old one."90 While Blackstone did not fully appreciate the creative role of judges, neither did he advocate slavish devotion to original legislative intent. He urged that "the most universal and effectual way of discovering the true meaning of a law, when the words are dubious, is by considering the reason and spirit of it . . . [f]or when this reason ceases, the law itself ought likewise to cease with it."91 While Blackstone refused to allow courts to substitute their judgment for that of the legislature, even when the legislature has "positively enact[ed] a thing to be done which is unreasonable," he did allow judges "to expound the statute by equity" to reject unreasonable consequences "where some collateral matter arises out of the general words" of the statute. ${ }^{92}$ To the extent that Blackstone had a theory of statutory interpretation, it was that judges should enforce the textual commands of statutes, though not to the detriment of the statute's overall purposes and the current demands of equity. That theory is closer to my model of dynamic interpretation than it is to any original intent approach.

Several of the influential Framers of the Constitution were at least as flexible as Blackstone in their approach to statutes. Alexander Hamilton went beyond Blackstone in The Federalist No. 78 in favoring a

${ }^{89}$ As I did above in the discussion of the formalist model, I assume here that a formalist who believes we should interpret statutes to find original intent would interpret the Constitution to find its original meaning.

90 $1 \mathrm{~W}$. BLACKSTONE, supra note 71, at 68-70.

91 Id. at 61; see Heydon's Case, 76 Eng. Rep. 637, 638 (Ex. Ch. 1584).

${ }_{22} 1 \mathrm{~W}$. Blackstone, supra note 71, at 91; see College of Physician's Case, 123 Eng. Rep. 928 (C.P. 1609). 
fairly broad power of federal courts to declare congressional enactments void and unconstitutional, and in arguing that courts should also have the power to control "unjust and partial laws" by "mitigating the severity and confining the operation of such laws." ${ }^{\text {93 }}$ His arguments derive from the checks and balances concept found in the Constitution: judicial frustration of unjust laws would force the legislature to "qualify" the severity of future laws. Hamilton further contended that everyone ought to support such judicial power, because "no man can be sure that he may not be tomorrow the victim of a spirit of injustice, by which he may be a gainer today" and "every man must now feel that the inevitable tendency of such a spirit is to sap the foundations of public and private confidence."

As William Blatt has recently demonstrated, Anglo-American approaches to statutory interpretation in the late eighteenth century were heavily influenced by equitable factors, including the doctrine of changed circumstances. ${ }^{98}$ It was not until the second half of the nineteenth century that the formalist approach-the role of a court interpreting a statute is only to divine and apply legislative intent-became the prevailing doctrine. This was part of a general shift in AngloAmerican law that emphasized the importance of will and choice. Just as scholars and judges redefined punitive damages in tort and criminal prohibitions in terms of malicious "intent," so legislative scholars redefined statutory interpretation as a search for legislative intent. In short, the formalist argument for strictly intentionalist statutory interpretation is ultimately not grounded in any constitutional vision held by the Framers. Rather, it reflects constitutional theory that was fashionable a hundred years later, and which has little persuasive power for our society today.

\section{The Comparative Law Response}

A further problem with the weaker statement of the formalist argument is that it has proven to be impractical, as demonstrated by the history of statutory interpretation in civil law countries. ${ }^{96}$ Since statu-

93 The Federalist No. 78, at 470 (A. Hamilton) (C. Rossiter ed. 1961); see D. EPSTEIN, supra note 66, at 189 (arguing that Hamilton suggested that "courts may be lenient against the lawmakers' intention").

94 The Federalist No. 78, at 470 (A. Hamilton) (C. Rossiter ed. 1961); see D. EPSTEIN, supra note 66, at 188-90 (stating that the Framers generally endorsed a liberal, equity-based approach to statutory interpretation).

${ }_{85}$ See Blatt, The History of Statutory Interpretation: A Study in Form and Substance, 6 CARDozo L. REv. 799, 802-05 (1985) (discussing Blackstone's view of statutory interpretation).

OB The general discussion in this section is indebted to N. HoRN, H. KoTz, \& H. 
tory law is considered the only formal source of authority and judges have no historical common law powers, civil law countries have a tradition of legislative supremacy that is stronger than it is in the United States. Indeed, in the eighteenth and nineteenth centuries, European civil law systems were even reluctant to vest courts with the power to interpret statutes. ${ }^{97}$ By the late nineteenth century, the rhetoric of statutory interpretation in civil law countries was strongly intentionalist. ${ }^{\mathbf{9 8}}$

Over time, however, the civil law has recognized three instances in which interpretation is not a search for legislative intent. The first instance is the "unclear statute," where neither the statutory text nor its legislative history provides a determinate answer. The second instance is "lacunae," or gaps in the statute's coverage. ${ }^{.9}$ The civil law codes typically instruct judges to interpret unclear statutes and fill in statutory lacunae by looking to analogous statutory rules, general principles of the state's legal order, and the justice or equity of the case. ${ }^{100}$ The third instance is the "anachronistic statute," whose meaning changes in response to significant changed circumstances. ${ }^{101}$ "A law, especially if it is old, need not be interpreted in the spirit with which it was conceived," but instead may "be rejuvenated by an interpretation conforming to the spirit of the times in which it is to be applied," accord-

Leser, German Private and Commercial Law: An Introduction 58-64 (1982) (T. Weir trans.); J. Merryman, The Givil Law Tradition: An InTroduction to the Legal Systems of Western Europe and Latin America 39-47 (2d ed. 1985); Zweigert \& Puttfarken, Statutory Interpretation-Civilian Style, 44 TUL. L. Rev. 705 (1970); see also R. David \& J. Brierly, Major Legal Systems in the WORLD TODAY 59-66 (2d ed. 1978).

97 Eighteenth-century Prussia adopted an exhaustive code with more than 17,000 articles and created a quasi-legislative "Statutes Commission" to which judges were supposed to refer issues of statutory interpretation. France, in the early nineteenth century, gave courts the power to interpret statutes subject to correction by a quasi-administrative tribunal of cassation. By the end of the century, both states mitigated their formalism and gave courts the power to interpret statutes, subject to review by a higher court. See J. MerRyman, supra note 96, at 39-41.

${ }^{88}$ Typical was the rule found in the Italian civil code, "Interpretation of Statutes: In applying the statutes, no other meaning can be attributed to them than that made clear by the actual significance of the words . . . and by the legislative intent." CoDice Givile [C.c.], art. 12 (Italy).

99 See J. MerRyman, supra note 96, at 43-47.

100 The Italian civil code further provides: "If a controversy cannot be decided by a precise provision, consideration is given to provisions that regulate similar cases or analogous matters; if the case still remains in doubt, it is decided according to the general principles of the legal order of the State." C.c., art. 12 (Italy). See BürGERLICHES GeseTzBuch, art. 7 (Austria) (similar); Gódigo Givil, art. 16 (Argen.) (if a civil law issue cannot be resolved through either the language or spirit of the law, it shall be referred to principles of analogous laws; if there is still no answer, it shall be resolved by reference to general principles of law, considering the circumstances of the case).

101 See J. Merryman, supra note 96, at 43-47. 
ing to one prominent civil law commentator. Such statutes must be liberally adapted to "realities and exigencies of modern life," and construed consistently with "sane reason and a natural spirit of justice."102

The actual practice of civil law judges has been somewhat less open-textured than the "evolutive" interpretation urged by the commentators, but they have been willing to read general statutes dynamically when societal or legal circumstances have decisively changed. A recent example is the liability of manufacturers for defects in their products. ${ }^{103}$ Givil code provisions traditionally have imposed liability on the manufacturer only if the manufacturer had been negligent or if there had been privity of contract between the victim and the manufacturer. As the legal community rejected such restrictive ideas of manufacturers' liability, the judges in several of the civil law countries reinterpreted the relevant code provisions to ease the victim's burden of proof. ${ }^{104}$ Thus, article 823 of the German Civil Code imposes tort liability on a defendant who "unlawfully injures the life, body, health, freedom, property or any other right."105 German courts long interpreted culpability as negligent or intentional conduct by the defendant, and negligence as the want of due care that a reasonable person would exercise in a given situation. The German Bundesgerichtshof reinterpreted article 823, paragraph 1, in the celebrated "fowl pest case," holding that in products liability cases there would be a presumption of negligence if the product were defective. ${ }^{106}$ The court justified its decision as evolutive interpretation: even though there was an applicable code provision whose original intent and purpose were clear, a more modern interpretation was needed to do justice in a growing number of cases. $^{107}$

$1021 \mathrm{H}$. DePage, Traité Élémentaire de Droit Givile Belge 513-15 (1962); see 1 H. KozIOI. \& R. WELSER, GRUNDREISS DES GURGERLICHEN RECHTS 15-16 (5th ed. 1979); 1 J.J. Llambias, Tratudo de Derecho Crvil 107-17 (2d ed. 1964); see also Zweigert \& Puttfarken, supra note 96, at 707-08 (if a code provision ceases to conform to current law and social order, it will be reinterpreted).

${ }^{103}$ Discussion in this paragraph is indebted to N. HORN, H. KoTz \& H. LESER, supra note 96, at 154-60 (German law); Orban, Product Liability: A Comparative Legal Restatement-Foreign National Law \& the EEC Directive, 8 GA. J. INT'L \& Comp. L. 342, 346-59 (1978) (surveying the development of products liability in civil law countries).

${ }_{104}$ See Orban, supra note 103, at 344-58 (France, Belgium, Switzerland, Scandanavia, Holland, and Germany).

105 BÜrgerl.ICHES GesetzBUCh [BGB], art. 823 (W. Ger.).

10851 BGHZ 91 (1969). The French cour de cassation has reinterpreted section 1384(1) of its Civil Code to avoid the statutory requirement of fault or knowledge when a manufacturer is sued for product defects, though the French court adopted a strict liability type rule rather than a presumption of negligence. See Orban, supra note 103, at 349 .

${ }^{107} 51 \mathrm{BGHZ}$ at 106-07. 


\section{The Jurisprudential Response}

The historical and comparative analysis developed above suggests a third response to the formalist argument. Intentionalist statutory interpretation has not been the product of the separation of powers idea; both the Framers in 1789 and modern civil law commentators have envisioned a system of separate powers, with legislative supremacy, but have contemplated dynamic interpretation of statutes to adapt to changed circumstances. Instead, intentionalist statutory interpretation has been the product of the "mechanical jurisprudence" of the late nineteenth century. ${ }^{108}$ Mechanical jurisprudence posits that law consists of rules promulgated by the sovereign legislature and mechanically applied by judges. The conception that the legislature has a specific "intention" on a wide range of interpretive questions, and that courts "objectively" determine that intention, is central to mechanical jurisprudence. ${ }^{108}$

Therefore, a central problem with intentionalist rhetoric is that subsequent jurisprudence in both the United States and Europe has rejected the assumptions of mechanical jurisprudence and, concomitantly, liberated judges to read statutes dynamically. The sociological and legal realist movements of the early twentieth century rejected the divorce of law from policy associated with mechanical jurisprudence and, more importantly, delegitimated the essential metaphors of intentionalist statutory interpretation. ${ }^{\mathbf{1 1 0}}$

To a substantial extent, the metaphor of judge as cipher has been replaced with the vision of a creative lawmaker whose judgment in "hard" statutory cases, where the statutory text does not answer the question determinately, rests in large part on the judge's subjective views of the statute and the justice of the particular case. In 1920, Judge Benjamin Cardozo confessed that the nature of the judicial process is "uncertainty" rather than objective answers, and that "the process in its highest reaches is not discovery, but creation."111 Although

108 Pound, Mechanical Jurisprudence, 8 Colum. L. Rev. 605 (1908); see Cox, Ruminations on Statutory Interpretation in the Burger Court, 19 VAL. U.L. REv. 287, 288-95 (1985) (providing a very scholarly review of the jurisprudence of statutory interpretation, starting with mechanical jurisprudence).

${ }_{109}$ See R. Pound, The SPIRIT of The Common Law 163-64 (1921).

110 The remainder of this section will focus on developments in the United States. For the effect of the new jurisprudence on European theories of statutory interpretation, see, e.g., F. GÉNY, MÉthode D'INTERPRÉTATION ET SOURCES (1899); P. HeCK, BEGRIFFSBILDUNG UND INTERESSENJURISPRUDENZ (1932).

111 B. Cardozo, The Nature of the Judicial Process 166 (1921) (published form of the 1920 Storrs Lectures at Yale); see J. Frank, LAw AND THE ModERN Mind 138-41, 207-09 (1st ed. 1930); H.L.A. HART, The CONCEPT OF LAW 11937 (1961); White, supra note 82 , at $49-50$. 
Cardozo and his contemporaries usually spoke of judicial creativity in connection with the judge's common law powers, they clearly saw the judge's creative role extending to statutory interpretation as well. ${ }^{112}$

Just as the realists debunked the mechanical ideal of the passive judge, so they derided the anthropomorphism of legislative "intent." Max Radin argued that the concept of a single "will" for a collective body is incoherent and, in any event, is not even necessary for a thoroughgoing formalism. ${ }^{113}$ According to Radin, the constitutional task of the legislature is not to have a "will," but only to write statutes, which are then interpreted and applied by judges and administrators to specific circumstances. ${ }^{114}$ Statutes are instruments of social policy, not ends in themselves, argued Radin. Other thinkers of the period developed the insight that percipient statutes, those responsive to genuine social and economic needs, would have an expansive influence on society and the common law itself. ${ }^{115}$

The criticisms made by the legal realists are accepted widely today. Scholars from a variety of viewpoints agree that the idea of legislative intent is incoherent and that judges have substantial lawmaking discretion in applying statutes. ${ }^{116}$ But the realists were not successful in replacing the obsolete theory of statutory interpretation with a modern one. Radin himself proposed that statutory interpretation should start

112 " $[\mathrm{I}] \mathrm{n}$ truth, all the Law is judge-made law. The shape in which a statute is imposed on the community as a guide for conduct is that statute as interpreted by the courts. The courts put life into the dead words of the statute." J. GRAY, The NATURE and Sources of THE Law 125 (1921); see R. Pound, supra note 109, at 170-75 (arguing that judicial interpretation is always required to fill in gaps left by statutes).

113 See Radin, Statutory Interpretation, 43 HaRv. L. REv. 863, 871-72 (1930). But see Landis, A Note on "Statutory Interpretation," 43 HARv. L. REv. 886, 892 (1930) (disagreeing with Radin's reductionistic view of statutes).

114 See Radin, supra note 113 , at 871.

115 See Landis, Statutes and the Sources of Law, in Harvard Legal Essays 213 (1934); see also Pound, Common Law E Legislation, 21 HARv. L. REv. 383, 38386 (1908) (arguing that courts should receive statutes fully into the body of law and hold them of superior authority to judge-made rules on the same general subject); Stone, The Common Law in the United States, 50 HARv. L. REv. 4, 13 (1936) ("[N]o adequate reason [exists] for our failure to treat a Statute much more as we treat a judicial precedent, as both a declaration and a source of law, and as a premise for legal reasoning.").

116 Recent analyses of the incoherence of legislative intent include R. DwORKIN, supra note 1, at 317-27; Moore, supra note 14, at 348-58. But see R. DickERson, supra note 4, at 73-74 (arguing that group intent, although different from the constituent individual intents, can be identified). Recent analyses of the decisionmaking discretion of judges interpreting statutes include S. BuRTON, AN INTRODUCTION TO LAw AND LEGAL REASONING 93-98 (1985) (arguing that judicial discretion maintains legitimacy so long as it is adequately supported by authoritative rules and principles); H.L.A. HART, supra note 111, at ch. 7 (stating that the "open texture" of the language of statutes affords discretion in interpretation); Posner, supra note 7, at 186-90 (arguing that legal formalism and realism have no application to statutory law). 
with the text, which will often provide determinate answers. Where the text does not provide a clear answer, the court should determine what "mischief" the legislature had targeted in passing the statute and then should interpret the statute to attack that mischief as it is manifested under current circumstances. ${ }^{117}$

The approaches to statutory interpretation suggested by the legal realists and their intellectual relatives, the legal process thinkers, ${ }^{118}$ demonstrate that respect for the Constitution's separation of powers, with Congress as the supreme lawmaking institution, does not philosophically or logically compel courts to adhere strictly to intentionalist statutory interpretation. Indeed, developments in the new "jurisprudence of interpretation" of the last two decades decisively undermine the coherence of the formalist argument for intentionalist interpretation and support my dynamic model. For the hard cases, interpretation will inevitably be affected by the current context of the judicial interpreter, and the greater the distance between the current and the historical context of the statute the more unlikely it is that intentionalist interpretation is even possible. ${ }^{110}$

Earlier in the century, the legal realists attacked intentionalist or literalist interpretation of legal texts by invoking the indeterminacy of language, especially the concept-oriented terms, such as "malice" or "discrimination," favored by statutory drafters. ${ }^{120}$ If the drafter's con-

, 117 Radin, A Short Way with Statutes, 56 HARv. L. REv. 388, 388-89, 421-22 (1942) (citing to Heydon's Case, 76 Eng. Rep. 637 (Ex. Ch. 1584)) (arguing that statutory law is primarily a corrective for flaws in the common law); see Blatt, supra note 95, at 829-30 (discussion of mischief rule). Other legal realists set forth similar, but even less precise, theories of dynamic statutory interpretation. See, e.g., Llewellyn, supra note 5, at 401-06 (listing and debunking canons of statutory construction); Frank, Words \& Music: Some Remarks on Statutory Interpretation, 47 CoLUM. L. REv. 1259, 1269-72 (1947) (comparing statutory interpretation to the interpretation of musical works by performers).

${ }^{118}$ H. HART \& A. SACKS, supra note 4, at 1410-17, "domesticated" the realists" approach to statutory interpretation by tying it to an idealized vision of legislative "purposes."

110 The following discussion has greatly profited from two recent multidisciplinary symposia on interpretation, though almost exclusively constitutional interpretation, in Interpretation Symposium, 58 S. CAL. L. REV. 1 (1985); Law and Literature: Symposium, 60 Tex. L. Rev. 373 (1982), and the recent skeptical caveats in Posner, Law \& Literature: A Relation Reargued, 72 VA. L. REv. 1351, 1360-61 (1986) (arguing that literary and legal interpretation are fundamentally different).

120 See Holmes, The Theory of Legal Interpretation, 12 HARv. L. REv. 417, 419 (1899) ("We do not inquire what the legislature meant; we ask only what the statute means."); see also Chafee, The Disorderly Conduct of Words, 41 Colum. L. REv. 381 (1941) (noting four lessons from the study of language that espouse its indeterminacy: the varied functions of language; the uncertain link between the word and the object; the changing meanings over time; and the hierarchical nature of words). For a recent version of this attack, see Moore, The Semantics of Judging, 54 S. CAL. L. Rev. 151, 180-81 (1981) (arguing that the linguistic context of legal texts makes semantic 
text, or intent, can never be perfectly discoverable in the hard cases, then the formalist claim to determinacy and objectivity is undermined. Even more troubling for the formalist vision is the critical importance of the interpreter's context, which is emphasized by the new jurisprudence of interpretation. ${ }^{121}$ "A sentence will never mean exactly the same thing to any two different people or even the same thing to one person on different occasions," argue some authors. "Meaning is shaped by the apperceptive mass of understanding and background that an individual brings to bear on the external fact of a sound or series of marks."122 A young black schoolteacher raised in Mississippi would approach the statutory issues in Weber differently than an elderly white doctor, not only because of different political biases, but because of different life experiences, education, and generational influences.

Modern humanistic scholarship inspires this insight. A persuasive, though still controversial, body of modern aesthetic theory rejects the concept that a text has a single "true" meaning and posits that meaning is constructed by the interaction of readers and text. One leading theorist, Hans-Georg Gadamer, has argued that interpretation of a historical text involves a "fusing of horizons," in which the reader reaches out to the past perspective, understanding that her present context conditions her comprehension of that text. ${ }^{123}$ Gadamer and subsequent critics further emphasize that interpretation of a canonical text is an ongoing dialectical process. Interpretation is a contemporary interpreter's dialogue with the text and with the tradition that surrounds it. ${ }^{124}$

problems such as ambiguity, metaphor, and vagueness inescapable).

122 For examples of this new jurisprudence, see Abraham, Statutory Interpretation and Literary Theory: Some Common Concerns of an Unlikely Pair, 32 RUTGERS L. REv. 676, 683-88 (1980); Dworkin, Law as Interpretation, 60 TEX. L. REv. 527, 527 (1982) (legal practice is fundamentally an exercise in interpretation, and "so conceived is deeply and thoroughly political"); Hoy, supra note 11, at 137-38; Levinson, Law as Literature, 60 TEx. L. REv. 373, 377 (1982) ("If we consider law as literature, then we might better understand the malaise that afflicts all contemporary legal analysis."); White, The Text, Interpretation \& Critical Standards, 60 TEx. L. REv. 569,584 (1982) (meaning of texts emerges from a complex interrelation between text and context, including that of the interpreter).

122 Hutchinson \& Morgan, The Semiology of Statutes (Book Review), 21 HaRv. J. LEGIS. 583, 593 (1984).

${ }^{123}$ H. GADAMER, supra note 67, at 337. While Gadamer's work has provoked debate, it has drawn a solid group of influential defenders. See D. HoY, supra note 11, at 41-100; F. KERMODE, supra note 11, at 26-28; J. WeINSHEIMER, supra note 11. Taking Gadamer's theory several steps further, Stanley Fish, in Is THERE a TEXT IN This CLAss? 94 (1980), argues that readers are not "passive and disinterested comprehenders of a knowledge external to them" and are "at every moment creating the experiential spaces into which a personal knowledge flows."

${ }^{124}$ D. HoY, supra note 11 , at 167. See generally F. KeRMOde, The Genesis of SECRECy: ON THE INTERPRETATION OF NARRATIVE (1979). Biblical scholarship (which inspired some of these modern literary theorists) distinguishes between "exege- 
This contextual literary theory finds its complement in the historiographical model of dynamic historical interpretation advanced, in different formats, by Professors Edward White ${ }^{125}$ and William Nelson. ${ }^{126}$ These scholars suggest that facts about the past are without meaning until they are woven into a story by the historian. Thus, in choosing which facts to emphasize and how to interpret them, the historian will often make choices based upon factors extrinsic to pure research. Although history is continuously refined through testing hypotheses against the facts, the story it tells will be decisively influenced by the "meta-theories," the overarching views of the world, held by the historian.

Although debated in their respective disciplines, these theories of subjective interpretation represent a growing academic consensus ${ }^{127}$ that different interpreters over time are likely to interpret the same text differently. Smith v. Wade illustrates this point. The authors of the majority opinion and the primary dissenting opinion were amateur historians who read the same text and historical evidence. Yet they wrote vastly different stories about the punitive damages rule in 1871. Each author seems sincerely committed to his different story. The different intellectual and personal perspectives of the interpreters themselves probably account for the differing positions. My own account of the history (which I think is a more sophisticated account) is similarly influenced by theories of torts and criminal law that I believe, my own evolutionary concept of history, and perhaps an iconoclastic desire to deconstruct a Supreme Court opinion and its main dissenting critique.

Even the moderate form of contextualist interpretation theory is fatal to the formalist argument for originalist statutory interpretation. It denies the possibility of consistent and objective interpretations of the same statute by different judges-or even by the same judges under different circumstances. On the other hand, moderate contextualism does not assert that the interpreter is entirely unconstrained. One interpretation can still be "better" than another, ${ }^{128}$ because it is more consistent with the historical or evolutive perspectives, or with both. In

sis," the discovery of a text's historical meaning, and "hermeneutics," the application of the text to current problems and circumstances.

125 See White, supra note 121 , at 569.

${ }^{128}$ Nelson, History and Neutrality in Constitutional Adjudication, 72 VA. L. REv. 1237, 1240-45 (1986).

${ }_{127}$ The literary theories of $H$. Gadamer and F. Kermode, see supra notes 11, 67, 123-24, fall between the views of authorial intent of E.D. Hirsh in THE AIMS - OF INTERPRETATION (1976) and VALIDITY OF INTERPRETATION (1967) and the unbounded contextualism of the deconstructionist theory articulated by $\mathrm{J}$. Derrida in OF Grammatology (G. Spivak trans. 1976). See also J. Guller, supra note 11.

128 Cf. A Matrer of Principle, supra note 10, at 119. 
most cases-the "easy cases"-the text and the interpretive history of the statute will provide relatively determinate answers, or at least narrow the range of permissible debate. ${ }^{129}$ Thus, in Smith $v$. Wade, the narrowness of the debate between the majority and dissenting opinions is striking. Both contemporary common sense and the interpretive history of section 1983 precluded the dissenting opinions from arguing that punitive damages were not available or that prison inmates could not sue under the statute at all, although perfectly good originalist arguments could have been made for each proposition.

\section{B. Economic Arguments}

In addition to the new jurisprudence of interpretation described above, another school of legal philosophy has contributed to theories of statutory interpretation: law and economics. In a seminal article, Professors William Landes and (now Judge) Richard Posner argued that if one assumes the Constitution embodies a simple economic/interest group vision of government, the independent "judicial Power" in article III can be justified as the efficient enforcement mechanism for legislative deals. ${ }^{130}$ Their argument is as follows. An economic theory of legislation posits that statutes are essentially "contracts" between interest groups and Congress. Congress passes laws in return for payments in the form of campaign contributions, votes, bribes, and promises. "In short, legislation is 'sold' by the legislature and 'bought" by the beneficiaries of the legislation."131 If statutes are contracts, enforcement becomes a problem. In a private market, contracts are enforced by legal sanctions or the threat of invoking them. In the market for public contracts--statutes-the role of the independent judiciary is to assure interest groups that their statutory bargains will be fulfilled. This guarantees the "stability . . . necessary to enable interest group politics to operate in the legislative arena." The bottom line, therefore, is that "an independent judiciary" which enforces statutes according to

129 See Schauer, Easy Cases, 58 S. Gal. L. Rev. 399, 414-20 (1985).

${ }_{130}$ Landes \& Posner, The Independent Judiciary in an Interest-Group Perspective, 18 J.L. \& EcoN. 875, 877-79 (1975).

132 Id. at 877 . The application of economic theory to explain public conduct is called "public choice theory" and is explained in J. Buchanan \& G. Tullock, ThE Calculus of Consent (1962); D. Mueller, Public Choice (1979); see Becker, A Theory of Competition Among Pressure Groups for Political Influence, 98 Q.J. EcoN. 371 (1983) (arguing that political equilibrium depends on the efficiency of each group in producing pressure, the effect of additional pressure on their influence, the number of persons in different groups, and the deadweight cost of taxes and subsidies); Stigler, The Theory of Economic Regulation, 2 BeLL J. Econ. \& MGMT. ScI. 3 (1971) (arguing that industrial regulation operates primarily for the benefit of the affected industry). 
their original intent "facilitates rather than, as conventionally believed, limits the practice of interest group politics."132

This model of legislation has stimulated a great deal of theorizing about statutory interpretation. Judge Frank Easterbrook has argued from this model that "public interest statutes" should be liberally interpreted, while "private interest statutes," the vast majority of the laws passed by Congress, should be narrowly confined to their express terms. ${ }^{133}$ Judge Posner has argued from this model that the job of courts is in most instances "imaginative reconstruction" of the legislature's probable intention. ${ }^{134}$ Professor Jonathan Macey has argued from a revised economic model of legislation (which posits as the goal of government the creation of public-seeking policy, not the ratification of private deals) that courts should interpret statutes to subserve their original purposes. ${ }^{185}$

The economic theory of legislation does not preclude my dynamic model of statutory interpretation, in part because the assumptions of the theory limit its applicability in our constitutional system. The Constitution, both originally and as it has evolved, contemplates that statutes will represent something more than transactions between interest groups and the Congress. Within its own assumptions, moreover, the economic theory of legislation supports dynamic statutory interpretation of "common law statutes" such as section 1983. ${ }^{136}$ Since all statutes are common law statutes to some extent, economic theory should not preclude dynamic statutory interpretation. Finally, even under a rigorous economic theory that treats statutes as contractual deals, courts should have the power to update the deal to adjust to changed circumstances.

132 Landes \& Posner, supra note 130 , at 878-79.

133 See Walton v. United Consumers Club, Inc., 786 F.2d 303, 310 (7th Cir. 1986) (Easterbrook, J.) (construing Fair Labor Standards Act, 29 U.S.C. $§ \S ~ 201-16$ (1982 \& Supp. III 1985) broadly); United States v. Medico Indus. Inc., 784 F.2d 840, 844 (7th Cir. 1986) (Easterbrook, J.) (construing federal conflict of interest statute, 18 U.S.C. § 207 (1982 \& Supp. II 1984 \& Supp. III 1985) narrowly); Easterbrook, The Supreme Court, 1983 Term-Foreword: The Court and the Economic System, 98 HARV. L. Rev. 4, 14-17 (1984); see also Easterbrook, supra note 3, at 544 (arguing that if a statute does not clearly and on its face apply to an interpretive question, the statute is irrelevant).

134 See R. PosNer, supra note 3, at 286-93 (disagreeing with both Judge Easterbrook and Hart \& Sacks); Posner, supra note 3, at 817-22; see also Posner, supra note 7, at 199 ("The task of interpretation is made neither irrelevant nor impossible by a failure of clear communication. The [courts] must determine what [the legislature] would have wanted [them] to do to advance the common enterprise under conditions of broken communication.").

135 See Macey, supra note 4, at 226-27.

138 See R. Posner, supra note 3, at 288. 
1. The Constitution Commits Our Polity to Deliberative Government That Promotes the Common Good, Not Just the Enforcement of Private Deals

The Landes and Posner model of statutory interpretation is a thought experiment that makes the explicit assumption that the Constitution sanctions interest group government. ${ }^{137}$ Historians continue to debate whether the Constitution embraces an interest group form of government. But it is now the prevailing view that the Constitution does not embody a classical "liberal" vision of government as nothing more than the arena where interest groups fight their battles. ${ }^{138}$

For decades, historiographical analysis focused on Charles Beard's thesis that the Constitution was itself a result of special interest "capture" of American government and hence implicitly ushered in the modern special interest government. ${ }^{139}$ The specific Beard thesis is a dead issue, and the focus of debate has shifted to delineate exactly what visions of law and society divided those who favored the Constitution, the Federalists, and those who opposed it, the Anti-Federalists. The "consensus historians" of the 1950's argued that the Federalists and Anti-Federalists agreed about most issues and came from similar socioeconomic backgrounds, ${ }^{140}$ and scholars in the 1960's and 1970's have

${ }^{137}$ Landes \& Posner, supra note 130, at 894 \& n.36; of. Macey, supra note 4, at 233-34 (describing the Landes and Posner model as one that accepts the Constitution as "designed to promote interest group domination of the legislative process [whereby] the judiciary, by enforcing the deals struck by such groups, [becomes] part of this design").

${ }_{138}$ See Ackerman, The Storrs Lectures: Discovering the Constitution, 93 YALE L.J. 1013, 1038-40 (1984) (arguing that our dualistic lawmaking system allows for individual liberalism while protecting against political advantage-taking by well-organized special interest groups); Sunstein, Interest Groups in American Public Law, 38 STAN. L. Rev. 29, 45-48 (1985) (Framers' view included both deliberative republican as well as interest-group liberal components.).

${ }^{139}$ C. Beard, AN Economic Interpretation of the Constitution of the UNITED STATES 188 (1913) ("[The Constitution] was an economic document drawn with superb skill by men whose property interests were immediately at stake; and as such it appealed directly and unerringly to identical interests in the country at large."). Beard's critics include R. Brown, Charles Beard and the Constitution 73-92 (1956) (arguing that a delegate-by-delegate analysis of the economic interests of the members of the Convention discredits Beard's conclusions); F. MCDonald, WE ThE People: The Economic Origins of the Constitution 38-92 (1958) (questioning Beard's assumption that there was a fundamental antagonism between personalty and realty interests at the Philadelphia Convention); E. MORGAN, BIRTH OF THE REPUBLIC, 1763-89, at 130-33 (1956) (stating that public spirit, rather than private selfishness, motivated the Founding Fathers). See generally Essays ON THE MAKING OF THE Constitution (L. Levy ed. 1969); The Reinterpretation of the AMERICaN Revolution 1763-1789 (J. Greene ed. 1968).

${ }_{140}$ See Elkins \& McKitrick, The Founding Fathers: Young Men of the Revolution, 76 PoL. ScI. Q. 181, 203-06 (1961) (generational differences were critical; Federalists tended to be young turks seeking to instill their energetic vision in the polity, while Anti-Federalists were older and more inert); Kenyon, Men of Little Faith: The 
focused on the pervasive influence of the "republican" tradition on both groups. ${ }^{141}$ Thus both groups believed, to some extent, in the concept of "virtue," the notion that government should promote the "common good" and avoid the corruption of private interests. What divided the groups ideologically was how to foster public virtue. The Anti-Federalists believed that the vices of corruption and faction could be rooted out by local government through education and moral reformation, while the Federalists believed that these evils could not be eliminated, but only controlled by the structural features of a national government.

The Federalist position is most intelligently explored in Madison's The Federalist No. 10.142 Madison's concern in the essay is control of "factions," which he defined as "a number of citizens, whether amounting to a majority or minority of the whole, who are united and actuated by some common impulse of passion, or of interest, adverse to the rights of other citizens, or to the permanent and aggregate interests of the community."143 Factions, therefore, include both pluralist interest groups and republican collections of passionately concerned citizens. Their potential evil is their threat to individuals, a concern of liberalism, and their threat to the public good, a concern of republicanism. Unlike the Anti-Federalists, Madison did not believe education and civic activity would reduce a democracy's tendency to factionalism, because the causes of faction are rooted in human nature. Instead, Madison contended that the best way to avoid control by temporary factions is to diffuse power among the three branches of government, including the two chambers of the legislature, and to extend the sphere of representation at the national rather than the state level. The checks

Anti-Federalists on the Nature of Representative Government, 12 WM. \& MARY Q. (3d Ser.) 3, 37-38 (1955) ("T The Federalists and Anti-Federalists] shared a large body of political ideas and attitudes, together with a common heritage of political institutions.").

141 See J.G.A. Pocock, The Machiavellian Moment: Florentine PolitiCal. Thought and the A trantic Republican Tradition 506-52 (1975); Hutson, Country, Court and Constitution: Antifederalism and the Historians, 38 WM. \& MARY Q. (3d Ser.) 337, 356-68 (1981) (portraying Anti-Federalists as sharing with the Federalists misgivings about direct democracy); Shalhope, Toward a Republican Synthesis: The Emergence of an Understanding of Republicanism in American Historiography, 29 WM. \& MARY Q. (3d Ser.) 49, 72-73 (1972) (stating that both the Federalists and the Anti-Federalists firmly believed themselves to be the true servants of republicanism). For a recent analysis, see Michelman, supra note 8, at 17-20.

142 The Federalist No. 10 (J. Madison) (C. Rossiter ed. 1961); cf. A. Furtwangler, The Authority of Publius: A Reading of the Federalist PaPERS 146-48 (1984) (The Federalist Papers should not be taken as canonical guides about what the Constitution means, but only as the most candid and intelligent discussion of the themes prominent in the minds of leading Federalists.). My discussion in this paragraph is largely a distillation of D. EPSTEIN, supra note 66, at 59-110.

143 The Federal.ist No. 10, at 78 (J. Madison) (C. Rossiter ed. 1961). 
and balances among various officials and the extended process of lawmaking and law application would, Madison hoped, ensure public-regarding deliberation before laws were enacted. ${ }^{\mathbf{1 4 4}}$ Bruce Ackerman has argued that the lesson of The Federalist No. 10 is that the Constitution contemplates more than just interest group pluralism. ${ }^{145}$ Ackerman's essay is realistic in appreciating that groups sharing similar economic interests or political views will try to effectuate those interests or views through the government, sometimes causing injustice to individuals or undermining the public good. Often legislation will represent nothing more than the triumph of faction. But the aspiration of the Constitution is that government do more than merely acquiesce to the demands of powerful factions. The Constitution expects that government will be deliberative, thereby compelling factions to consider the interests of others and the public welfare, and will at least occasionally rise above factions to implement and expand the common good.

Ackerman's vision of a Constitution that contemplates both liberal and republican traditions not only is historiographically superior to a simple interest group view of the Constitution, but also has current descriptive value. It reconciles two distinct scholarly traditions that analyze legislation. While many statutes are little more than private interest compromises, or even deals, ${ }^{146}$ most cannot be so narrowly defined. Descriptive political studies of Congress strongly dispute any simpleinterest group model of legislation. John Kingdon and other scholars have argued that normally the central participants in the legislative process are not private-seeking interest groups, but are instead publicseeking participants-the President and the Cabinet, agencies and bureaucrats, legislators and their staffs, academics and experts, the media and public opinion, and political parties. ${ }^{147} \mathrm{~A}$ recent empirical study indicates that the influence of interest group pressure on federal legislation ranges from "insignificant to determinative."148

144 Id. at $80,82-84$.

${ }^{145}$ Ackerman, supra note 138, at 1020-31; see Macey, supra note 4, at 243-44.

146 See, e.g., E.E. Schattschneider, Politics, Pressures and the Tariff: A Study of Free Private Enterprise in Pressure Politics, as Shown in the 1929-1930 REvision OF THE TARIFF (1935) (outlining method by which special interests may affect tariff decisions).

147 See J. Kingdon, Agendas, Alternatives, and Public Policies 48-74 (1984); see also A. MAass, Congress and The Common Good 5 (1983) (stating that "[i]nstead of conducting a political process that simply aggregates and reconciles narrow group or individual interests, government conducts a process of deliberation and discussion that results in decisions that are based on broader community interests"); Elliott, Ackerman \& Millian, Toward a Theory of Statutory Evolution: The Federalization of Environmental Law, 1 J.L. ECON. \& ORG. 313, 319-21 (1985).

148 K. Schlozman \& J. Tierney, Organized Interests and American DeMOCRACY 317 (1986). Two excellent and recent critiques of the capacity of public 
The implications of modern historical and political science scholarship severely undermine any theory which argues for intentionalist statutory interpretation based on an interest group model of legislation. On the one hand, even when interest group theory accurately describes the legislative process (statutes are private deals), the prevailing normative theory of the Constitution suggests that statutory interpretation is not limited to the enforcement of such deals and ought to have a publicseeking thrust. On the other hand, it is apparent that interest group theory does not adequately explain many statutes. For the statutes that were enacted after a deliberative process, subsequent judicial interpretation should continue the process of deliberation and development of the common good embodied in the statute, since the common good changes over time. For example, the Civil Rights Act went through unusually thoughtful and public-seeking deliberation before it became law in 1964. ${ }^{148}$ The Supreme Court's dynamic interpretation of Title VII in Weber continued the government's commitment to the public values in Title VII in light of changed circumstances that threatened to undermine those values decisively.

\section{In a Government Seeking the Common Good, Economic Analysis Requires Dynamic Statutory Interpretation}

In recent works, Judge Posner endorses the idea that statutory interpretation in our constitutional system often cannot be limited to intentionalism. Thus, generally worded statutes such as the Sherman Act and section 1983 are not governed by his principle of imaginative reconstruction of the legislature's intent and should be interpreted to achieve the most reasonable results in light of current policy. ${ }^{150}$ Judge Posner has suggested three reasons for reading such generally worded statutes dynamically. First, there is often not enough information to

choice theory to explain the legislative process are Farber \& Frickey, The Jurisprudence of Public Choice, 65 TEx. L. REv. 873 (1987), and Mashaw, Positive Theory and Public Law (Feb. 1986) (Rosenthal Lectures, Northwestern University Law School).

149 See generally W. Eskridge \& P. Frickey, Statutes and the Greation of Public Policy ch. 1, at $\S 1$ (1987) (the story of the Civil Rights Act of 1964 and the procedures of statute creation).

${ }_{100}$ See R. Posner, supra note 3, at 288; see also Forrester v. White, 792 F.2d 647, 658-59 (7th Cir. 1986) (Posner, J., dissenting) (dynamic interpretation of $\S 1983$ ), cert. granted, 107 S. Ct. 1285 (1987); United States v. Wolf, 787 F.2d 1094, 1100-01 (7th Cir. 1986) (Posner, J.) (suggesting that the term "immoral purpose" as used in the Mann Act, 18 U.S.C. $\$ 2421$ (1982) should be dynamically interpreted in light of this country's current sexual mores). See also Easterbrook, supra note 133, at 14-17 (arguing that "public interest" statutes, which are usually generally worded, ought to be interpreted expansively). 
determine how the original legislature would have wanted the statute to be interpreted. Reconstructing the historical intent of a relatively recent statute, as in Weber, is difficult enough; where the statute is very old and circumstances have changed dramatically, as in Smith $v$. Wade, it is well-nigh impossible. Second, the broad phrasing represents an implicit delegation of lawmaking authority to the courts; just as Congress explicitly delegates lawmaking responsibilities to administrative agencies, so it implicitly delegates similar lawmaking freedom to courts when it enacts generally worded common law statutes. ${ }^{151}$ Most recently, Judge Posner has suggested a third reason for reading statutes such as the Sherman Act dynamically: it makes sense as a matter of policy. ${ }^{152}$ Courts would not only fail in the effort to reconstruct the original intent and purposes of the Sherman Act, but the national economy would surely suffer as a result of any serious attempt to implement the original legislative expectations. When Congress has basically dropped a problem into the collective judicial lap, with imprecise and only general directions, then it makes sense for courts to develop that statute in accordance with contemporary, rather than purely historical, policy. I suggest, first, that these reasons for more flexible interpretation cannot be limited to generally worded statutes and, second, that this final reason is a powerful economic argument for dynamic interpretation in general.

These reasons apply not only to common law statutes such as section 1983 and the Sherman Act, but also to more detailed statutes such as Title VII. Congress's failure to define "discriminate" in Title VII permits-indeed, calls for-just as much judicial creativity as its prohibition of "restraints of trade" in the Sherman Act. In both instances, Congress has set forth general policy and has left courts substantial freedom to adapt the general language to changed circumstances. Title VII is, in that sense, a common law statute. The difference between Title VII and the Sherman Act is mainly the degree to which the statutory text limits judicial creativity: the very old, generally phrased text of the Sherman Act places few limits on courts, while the more recent text

152 See R. PoSNer, supra note 3 , at 288 . I find this reason less than completely satisfying. One searches in vain through the legislative history of $\$ 1983$, for example, for any suggestion that Congress thought it was delegating enormous law-creating powers to courts. Contemporary treatises on statutory interpretation as of 1871 mention no such implied delegation. See 1 W. Blackstone, supra note 71, at 63-70, 85-88; T. SEDGWICK, A TREatise ON THE RULES WhICH GOVERN THE INTERPRETATION AND Application of Statutory and Constitutional LAw 225-446 (1857) (describing general rules of statutory construction and manner of interpreting specific types of statutes).

102 Posner, supra note 7 , at 199. 
of Title VII, pockmarked with special compromises, does limit judicial freedom. Because most statutes have common law features, they need not be interpreted with strict regard to original legislative intent even under Judge Posner's approach.

Indeed, Judge Posner's recently articulated third reason for interpreting common law statutes dynamically implicates broader policy reasons. Specifically, a "transactional model" of the legislative process suggests that the' market for statutes is a poorly functioning one. Given the inherent problems with the legislative process and our polity's constitutional commitment to the common good, statutes ought to be interpreted dynamically.

Consider the peculiar "market" for legislation. ${ }^{153}$ The degree and nature of interest group organization and activity-the demand pattern in our statutory market -is determined by the perceived incidence of costs and benefits of legislation. Widely-distributed benefits, such as the protection afforded by the criminal laws or section 1983, do not often stimulate the creation of interest groups in favor of such legislation because each beneficiary has only a small stake in the benefit and hence will not bestir itself to invest time, energy, or money to obtain the benefit. Beneficiaries who do seek such legislation through collective action will be subject to the "free rider problem," in which they create public goods from which noncontributing beneficiaries cannot be excluded. The existence of this problem will further discourage groups from forming around the issue, and legislation will not be systematically demanded. For similar reasons, legislation with widely distributed costs, such as incremental increases in taxes or inflation, will usually not invite group formation to oppose such legislation. In contrast, the existence of concentrated costs or benefits-taxes or subsidies falling upon smaller and well-defined groups of actors-will tend to promote interest group formation, because each cost payer or beneficiary has a substantial stake in the outcome and has greater incentive and opportunity to coordinate its efforts with those similarly situated.

The receptiveness of legislators to these demand patterns-the supply pattern in our statutory market-is determined by the risks taken and by the benefits accruing to the legislator. The primary motivation of the legislator is to be reelected. ${ }^{\mathbf{1 5 4}}$ Therefore, she will try to

${ }^{153}$ The following simplified synthesis of transactional analysis of legislation is drawn from M. Hayes, LobByists and Legislators: A Theory of Political Markets (1981); M. Olson, The Logic of Collective Action (1965); J.Q. WilSON, Political ORganizations (1973); Salisbury, An Exchange Theory of Interest Groups, 13 Midwest J. POL. ScI. 1 (1969).

164 See M. Fiorina, Congress: Keystone of the Washington Establishment (1977); D. MAYhew, Congress: The Electoral Connection 13-77 (1974). 
avoid confrontation with groups of constituents. She will prefer "nonconflictual" demand patterns. Thus, the legislator will want to do nothing when there is no organized demand for legislation, especially if there is organized and informed opposition. Unhappily, the legislator cannot always avoid conflictual demand patterns, either because an issue is politically salient, or because an organized group is lobbying strongly. In that event, she has every incentive to delegate final decisions to another entity, the bureaucracy or the courts, or to adopt a compromise solution that makes concessions to various groups. The following chart summarizes the demand and supply tendencies of the four permutations of the cost and benefit patterns:

\section{A Transactional Model of Legislation}

\section{Distributed Benefits/}

\section{Distributed Costs}

Typically, very little organized activity. Response is legislative inaction, with symbolic reassurances to the electorate.

Concentrated Benefits/

Distributed Costs

Substantial organized activity supporting legislation, little organized opposition. Response is either self-regulation or distribution to the organized group.

Under this transactional model, our society is in trouble. ${ }^{155} \mathrm{We}$ have both too little and too much legislation. On the one hand, there is too little policy addressing common problems (distributed benefit laws), and such laws as are passed are generally not amended by the legislature to reflect changes in society or evolving attitudes about problems. ${ }^{158}$ On the other hand, there is too much policy aimed at satisfying organized special interest groups (concentrated benefit laws), which tend to accrue excessive government benefits for themselves, ei-

185 See M. Olson, The Rise and Decline of Nations: Economic Growth, Stagflation, and Social Rigidities 36-73 (1982) (dense networks of special interest groups act to retard economic growth and increase likelihood of social decay).

${ }_{188}$ See M. HAYES, supra note 153 , at $128-32,133-40$. 
ther through direct statutory transfers or by capturing the regulatory apparatus created by the statute. ${ }^{\mathbf{1 5 7}}$ Dynamic statutory interpretation by judges is one way to ameliorate-but by no means solve-this paradox of both too much and too little government.

From a utilitarian perspective, the public interest or public sentiment laws that are generally worded should be interpreted dynamically. By interpreting such laws in light of current policy, rather than historic intent, courts enable those statutes to grow and develop in response to novel fact situations and significant changes in the legal terrain. Since Congress cannot be expected to amend and update such statutes very often (because demand is spotty), courts can serve a useful role by interpreting such statutes to deal with new circumstances. For slightly different reasons, more detailed, special interest statutes should also be interpreted dynamically. Just as Hamilton urged that courts should "mitigat $[\mathrm{e}]$ and confin[e] the operation" of "unjust and partial laws"158 by construing them narrowly, so courts can, and ought, to mitigate special interest laws by interpreting them in light of current societal needs and evolving legal policy. For example, courts have read liberalized procedural rules into old regulatory statutes, changing the original legislative "bargain" in response to changed circumstances and legal values. ${ }^{159}$ Indeed, under an economic approach the real issue in Weber is not whether the original legislative "deal" contemplated voluntary affirmative action programs, but whether such programs really do contribute to the integration of minorities into our economic system. ${ }^{\mathbf{1 6 0}}$

3. Even If Statutes Were Transactions, They Should Be Interpreted Dynamically in Some Circumstances

Thus far I have not accepted the economic metaphor of statutes as contracts, in large part because the metaphor slights the value-creating

${ }^{157}$ See A. Downs, AN Economic Theory of Democracy chs. 11-13 (1957) (economic analysis of the way information costs affect participation in the decisionmaking process); M. Hayes, supra note 153, at 102-08; G. Tullock, Towards A Mathematics of Politics chs. 6-9 (1967) (same).

${ }^{168}$ The Federalist No. 78, at 470 (A. Hamilton) (C. Rossiter ed. 1961).

169 See Stewart, Regulation in a Liberal State: The Role of Non-Commodity Values, 92 YALE L.J. 1537, 1552-53 (1983) [hereinafter Regulation] (discussing historical changes in the conditions that prompted the creation of the Federal Communications Commission); Stewart, The Reformation of American Administrative Law, 88 HaRv. L. REv. 1667, 1723-56 (1975) (discussing evolution of judicial treatment of agencies' duties generally).

180 Compare Meltzer, supra note 46 (arguing that Weber is wrong because it violates the original legislative deal) with Kitch, The Return of Color Consciousness to the Constitution: Weber, Dayton, and Columbus, 1979 SuP. CT. REv. 1, 12-13 (arguing that Weber is wrong because it hurts blacks and contributes to race-consciousness). 
dimension of statutes. ${ }^{161}$ Even if the creation of statutes were essentially a transaction between private groups demanding legislation and public legislators supplying it, the result scarcely resembles a "contract," at least as contracts are conventionally understood. Unlike conventional contracts, the writing of a statute involves a variety of different parties, ranging from the President to private groups to staff members to the legislators themselves. Statutes run without term (in fact most statutes never expire), whereas contracts by their terms or by mutual expectation expire after a period of time. Similarly, statutes are often wholly open-ended, inviting litigation and further interpretation. Only a poorly drafted contract leaves as many open terms as a statute often does. Finally, unlike conventional contracts, statutes are inherently subject to unilateral revision and repeal.

Because of the peculiar nature of statutory "contracts," the traditional rule of contract interpretation, which instructs the court to apply the contract terms and the intent of the parties, is inadequate. For example, if section 1983 were a contract entered into a hundred years ago between Uncle Sam and his tenants-in-chief, The People, I doubt that a court interpreting the contract today would find sufficient defintion of the original intent of the contracting parties in its terms. To answer most questions of contract interpretation, the court would, in fact, consider current policy and practice through a series of what Professor Richard Stewart has called "suppletive rules"::162 (1) The contract might be updated by looking to current "usages of trade" generally, or "courses of dealing" specifically adopted by the parties. ${ }^{163}(2)$ The general obligations of "good faith" and "unconscionability" would protect against hundred-year-old terms that are no longer considered reasonable. ${ }^{164}$ (3) The contract might be cancelled or reformulated if performance had been rendered "impracticable" by the existence of contingen-

161 See Tribe, Constitutional Calculus: Equal Justice or Economic Efficiency?, 98 Harv. L. Rev. 592 (1985); $c f$. National R.R. Passenger Corp. v. Atchison, T. \& S.F. Ry., 470 U.S. 451, 467-69 (1985) (statute creating corporation with authority to contract did not bind federal government contractually to railroads).

162 See Regulation, supra note 159, at 1551. I note here the internal incoherence of any argument that favors intentionalist statutory interpretation based on the premise that statutes are like contracts. Whereas the intent of the legislature is critical to statutory interpretation, the governing intent in a contract is the mutual intent of the contracting parties.

18s See U.C.C. § 2-208 (1977); Restatement (Second) of Contracts $\S \S 222-23$ (1981).

104 See U.C.C. §§ 1-203 (duty of good faith), 2-302 (avoidance of enforcing unconscionable terms) (1977); of. Dawson, Effects of Inflation on Private Contracts in Germany, 1914-1924, 33 Mich. L. REv. 171 (1934) (German courts devised rules of revaluation of contract prices during hyperinflation period). 
cies not contemplated in the original contract. ${ }^{165}$ (4) Terms might be added to or subtracted from the original contract according to new policies embodied in modern contract law. ${ }^{168}$ (5) The court might treat the contract as a "relational contract," in which the parties are only expected to expend their "best efforts" under the ongoing circumstances of the contract. ${ }^{167}$

In short, even if a statute were nothing more than an ordinary contract, its interpretation would be informed by current as well as historical factors. This becomes even more striking when one considers a better contract analogue-the consent decree. ${ }^{168}$ Like a statute under the transactional approach, the consent decree is negotiated between one or more private actors and one or more public actors. Like a statute, the consent decree endures for a long or indeterminate period of time, until it is withdrawn or amended, and must normally be accompanied by a public justification and object. Also, like a statute under my model of dynamic interpretation, the consent decree can be changed by the court, over the objections of a party, to reflect changed circumstances. ${ }^{169}$ Consent decrees exemplify dynamic interpretation because they often result in an ongoing process of revision to address new problems.

While the analogy to the consent decree may support the evolutive character of statutory interpretation, it also highlights what I believe is the central lesson of the economic theory of legislation: respect for recent legislative compromises. A court has very broad discretion in modifying a Sherman Act or section 1983 consent decree to reflect changed circumstances because the statutes are generally worded. But, as Stotts indicates, a court is more constrained in modifying a Title VII consent decree, because the statute is filled with detailed compromises such as

${ }^{168}$ See Aluminum Co. of Am. v. Essex Group, Inc., 499 F. Supp. 53 (W.D. Pa. 1980); Krull v. Henry, [1903] 2 K.B. 748; U.C.C. $§ \S ~ 2-615$ (excuse by failure of presupposed conditions), 2-616 (procedure on notice claiming excuse) (1977); RESTATEMENT (SECOND) OF CoNTRACTS § 261 (1981).

${ }_{168}$ See E. Farnsworth, ConTracts 523-25 (1982).

187 See MacNeil, The Many Futures of Contracts, 47 S. CAL. L. REv. 691, 72026 (1974); Scott \& Goetz, The Mitigation Principle: Toward a General Theory of Contractual Obligation, 69 VA. L. REv. 969, 1001-23 (1983).

${ }_{168}$ The discussion in this paragraph is inspired and informed by the seminal treatment in O. Fiss, INJUNCTIONS ch. 2 (1972).

${ }_{189}$ See Evans v. Jeff D., 106 S. Ct. 1531, 1537 n.12 (1986); Firefighters Local Union No. 1784 v. Stotts, 467 U.S. 561, 576 n.9 (1984); United States v. Swift \& Co., 286 U.S. 106, 114 (1932). There is a distinction in the case law between "interpreting" and "modifying" a consent decree. The Court has favored an originalist approach for interpreting the "four corners" of a consent decree, see United States v. Armour \& Co., 402 U.S. $673,681-82(1971)$, but the cases cited above give courts the power to modify the decree to reflect changed circumstances. 
the protection of bona fide seniority systems in collective bargaining agreements. ${ }^{170}$ While these compromises-call them deals if you like-may undermine the coherence of the statute, they also should be enforced as part of the "original bargain" made in the United States Constitution.

\section{The Countermajoritarian Difficulty with Reading Statutes Dynamically}

A legal process objection to dynamic interpretation is suggested by the "countermajoritarian difficulty" that the late Alexander Bickel raised in connection with judicial review. ${ }^{171}$ Although some of the Framers and subsequent scholars have tried to slide over the difficulty by characterizing judicial review as nothing more than the assertion of the constitutional superiority of "the power of the people" over the "will of the legislature,"172 the fact remains that it is a nonelected judge asserting lawmaking power over the duly elected representatives of the people. Even though Bickel did not claim that the Republic was in imminent danger because of active judicial review and did not tie his argument rigorously to a vision of the Constitution, his argument was persuasive because it articulated the anxiety remaining from the discredited period of Lochnerian judicial review. ${ }^{173}$ Bickel's challenge to the "legitimacy" of judicial activism was based upon his view that activist judges may thereby be substituting their own "personal values" for legislatively determined values. This is inconsistent with our society's fundamental commitment to democracy.

Bickel's concerns may apply to statutory interpretation that slights the original value choices of the legislature. The countermajoritarian difficulty, however, ought not to be the basis for rejecting a cautious model of dynamic interpretation such as that set forth here. For example, when there has been a significant change in circumstances, the countermajoritarian difficulty presents slight justification for continuing to treat old statutory majorities as decisive and controlling. Additionally, other political values, apart from majoritarianism, are important in our constitutional polity. The legitimacy of government is ultimately

170 See Stotts, 467 U.S. at 576 n.9.

171 "The root difficulty is that judicial review is a counter-majoritarian force in our system." A. Bickel, The Least Dangerous Branch 16 (1962); see Kronman, Alexander Bickel's Philosophy of Prudence, 94 YALE L.J. 1567, 1573-79 (1985).

${ }^{172}$ See BICKEL, supra note 171, at 16-17 (discussing rationalizations offered by Alexander Hamilton in The Federalist No. 78 and by Chief Justice John Marshall).

${ }^{173}$ See Ackerman, supra note 138, at 1013-15. 
based upon the continued responsiveness of the whole government to the objective needs of the evolving society. Under this view of legitimacy, the constructive role of courts in interpreting statutes by reference to current problems and policies can be quite substantial. This is not to say that the judge's role will be overwhelming. Given the incremental, precedent-oriented nature of the judicial process and the availability of statutory correction of judicial errors, there are some assurances that dynamic statutory interpretation will not undermine the correctional operation of our representative government.

\section{Is Dynamic Statutory Interpretation Significantly Countermajoritarian?}

In defending his thesis that courts should have the power to overrule statutes, just as they overrule common law decisions, Professor (now Dean) Guido Calabresi has analyzed several responses to the countermajoritarian concern. ${ }^{174}$ While I find none of the responses completely dispositive of that concern, they do effectively minimize it and suggest that my cautious model of dynamic interpretation is not significantly countermajoritarian.

One response analyzed, but not endorsed, by Calabresi is that nonconstitutional judicial treatment of statutes is only conditional, for it may be "corrected" by legislative action. ${ }^{176}$ This argument seems intuitively inconsistent with the primacy accorded legislative policy making. ${ }^{176}$ More importantly, the possibility of legislative correction is not a true majoritarian check because it is not regularly invoked. Political theory and experience suggest that because of the many procedural obstacles to legislation in our bicameral committee-dominated Congress, the tendency of interest groups to block rather than advance legislation, and the deference that legislators and their staffs will typically give to virtually any decision of the Supreme Court, such legislative correction will rarely occur. ${ }^{\mathbf{1 7 7}}$ For example, most Americans probably did not

174 G. Galabresi, supra note 7, at 92-97.

${ }^{176} \mathrm{Id}$. at 92-93; see J.H. Ely, Democracy AND Distrust: A Theory of JuDICIAL REVIEW 4 (1980) (minimizing the countermajoritarian difficulty in "nonconstitutional contexts" because "the court's decisions are subject to overrule or alteration by ordinary statute").

176 G. Calabresi, supra note 7, at 92-93.

177 See A. BiCkel, supra note 171, at 206; Note, Congressional Reversal of Supreme Court Decisions: 1945-1957, 71 HaRv. L. REv. 1324, 1332-36 (1958). The standard source on the procedural obstacles is W. Oleszek, Congressional ProceDURES AND THE Policy Process (2d ed. 1984). See also B. Oppenheimer, Congress $\mathcal{E}^{\circ}$ the New Obstructionism: Developing an Energy Program, in CONGREss RECONSIDERED 275 (L. Dodd \& B. Oppenheimer eds. 2d ed. 1981) (asserting that procedural obstacles have become more troublesome after the procedural "reforms" in Congress 
agree with affirmative action, ${ }^{178}$ yet there has been no serious effort to overrule the Weber decision legislatively. Any proposal to do so would be highly conflictual, with intensely interested groups on either side of the issue, giving members of Congress substantial incentives to avoid taking stands on minority rights issues. ${ }^{179}$ Even if a bill to overrule Weber had majority support in Congress, it would probably face insurmountable procedural obstacles. ${ }^{180}$ Whatever the preferences of a majority of the country, or even of the Congress, a statute overruling Weber is highly unlikely.

In short, legislative inertia means that only occasionally and adventitiously will Congress respond to judicial statutory interpretations at odds with original intent or purpose. ${ }^{181}$ As Calabresi suggests, this reality leaves the countermajoritarian difficulty unsolved, but ameliorated: judicial lawmaking power only shifts the "burden of inertia"

during the 1970's).

178 A 1984 public opinion survey showed very little support for affirmative action. Affirmative Action: Substantial Majority of Americans Oppose Preferential Treatment for Women and Minorities, 224 GALluP REP. 28, 28-29 (1984). Ability, as determined by test scores, was favored over preferential treatment by $84 \%$ of the public and only $10 \%$ favored preferential treatment. Gallup polls in 1980 and 1977 produced virtually identical results. $I d$. at 29.

179 See M. FIorina, supra note 154, at 40-49 (legislators seeking re-election have disincentive to tackle controversial issues and great incentive to devote time to pork barrel legislation and constituent services).

180 In the House of Representatives, the Chair of the Judiciary Committee which would have jurisdiction over the bill (liberal Democrat Peter Rodino, who represents a district that is predominantly black) would intensely oppose such a bill and could effectively kill it by refusing to bring it up for consideration or by assembling a coalition to vote the bill down in committee. Even if it got out of the Judiciary Committee, it could die in the Rules Committee, whose liberal chair (Glaude Pepper) could similarly stall action indefinitely. In the Senate, even if the Judiciary Committee (chaired by liberal Joseph Biden) reported such a bill, the Democratic leadership (Robert Byrd and Alan Cranston) would be reluctant to bring the bill to the floor. If the bill made it to the floor, the liberals could kill it by extended debate (the filibuster, which the liberals borrowed for their own agenda from the conservatives of the 1960's). For a description of the path a bill takes through Congress, see W. Oleszek, supra note 177, at 15.

${ }_{181}$ For an example of legislative overruling, compare United Air Lines, Inc. v. McMann, 434 U.S. 192, 203 (1977) (an established mandatory retirement plan is not prohibited by the Age Discrimination in Employment Act of 1967), with Age Discrimination in Employment Act Amendments of 1978, Pub. L. No. 95-256, § 2, 92 Stat. 189, (codified at 29 U.S.C. $\$ 623$ (1982)) (including mandatory retirement based on age within the prohibitions of the ADEA) and H.R. REP. No. 950, 95th Cong., 2d Sess. 8, reprinted in 1978 U.S. CODE CONG. \& ADMIN. NEws 528, 529 (explicitly overruling McMann); and compare Tennessee Valley Auth. v. Hill, 437 U.S. 153, 18795 (1978) (the Endangered Species Act of 1973 required halting the completion of the Tellico Dam project in Tennessee in order to protect the snail darter), with Endangered Species Act Amendments of 1978, Pub. L. No. 95-632, 92 Stat. 3751 (codified at 16 U.S.C. $\$ \S 1531-1543$ (1982)) (allowing more flexible application of the provisions of the Endangered Species Act) and H.R. ReP. No. 1625, 95th Cong., 2d Sess. 10, reprinted in 1978 U.S. CODE CONG. \& ADMIN. NEws 9453, 9460 (explicitly mentioning $\mathbf{H i l l}$ ). 
from the original legislated preference to the newer judicial preference. ${ }^{182}$ While such a shifting of the burden of inertia is not majoritarian, neither is it blatantly countermajoritarian.

A second response, accepted by Calabresi as the best solution to the countermajoritarian difficulty, is that judicial lawmaking is justified by "the subservience of courts to principles, to rational decisionmaking, and to the whole fabric of the law."18s Because such "principled decisionmaking within a legal landscape [is] the primary judicial task," courts may, consistent with majoritarian democratic theory, be given lawmaking tasks based upon "the belief that the legal fabric, and the principles that form it, are a good approximation of one aspect of the popular will, of what a majority in some sense desires."184 This response, however, is not as persuasive as some commentators consider it to be, in part because it is rooted in the outdated rhetoric of mechanical jurisprudence, associating courts with reasoned, timeless "principle," and legislatures with irrational, contingent "politics." After its critique by the legal realists, that rhetoric has lost much of its cogency, and critical scholarship during the 1980's has rendered it increasingly controversial. ${ }^{185}$

More important, Calabresi's equation of the "legal landscape" with "one aspect of the popular will"188 is incoherent. On the one hand, the majority appears at times to be quite at odds with the legal

182 G. Calabresi, supra note 7 , at $93,94-101$.

183 Id. at 96.

184 Id. at 96-97. Calabresi also analyzes and rejects other responses to the countermajoritarian difficulty, such as the arguments that legislatures are not as majoritarian as they appear, see Hamm, Legislative Committees, Executive Agencies E Interest Groups, in HandBook of Legislative Research 573, 576-82 (G. Loewenberg, S. Patterson, \& M. Jewell eds. 1985); Ragsdale, Legislative Elections \& Electoral Responsiveness, in $i d$. at 57,88 , and that courts are not as unaccountable as their formal article III status would suggest. G. CAlabresI, supra note 7, at 93-94 \& n.10. Calabresi agrees with other commentators such as John Hart Ely that however sensitive the jurist and however encrusted the legislative process, legislators are subject to periodic review by the voters and hence have a structural incentive to be responsive to popular demands. Frankly, I find this unpersuasive, because most of the terrible things legislators do-or, more important, fail to do-are utterly obscured to the average voter, who returns the incumbent to office based on name recognition, high visibility, pork barrel projects, and so forth. See M. Fiorina, supra note 154, at 49. My views on this issue are not widely shared, and so I confine them to this footnote.

${ }^{185}$ See generally Peller, The Metaphysics of American Law, 73 CALIF. L. REv. 1151 (1985) (critical analysis of doctrine that law is separate from politics); Tushnet, Following the Rules Laid Down: A Critique of Interpretivism and Neutral Principles, 96 HARV. L. REv. 781 (1983) (theory that courts apply neutral principles presupposes a consensus that, if it existed, would make the theory unnecessary as a check on judicial lawmaking).

${ }^{188}$ See G. Calabresi, supra note 7, at 96-97. 
landscape. ${ }^{187}$ The legal landscape, after all, is mostly created by lawyers and other affluent groups in our society, and it would appear that its upper middle class values would frequently be at odds with those of mainstream America. ${ }^{188}$ On the other hand, even if it were true that the legal landscape enjoys majoritarian support, that does not prove that a majority of people would favor the existing legal landscape over other alternatives if such alternatives were explained to them. People accept most existing legal rules because they are the rules, not because people positively prefer them. ${ }^{180}$

Perhaps the primary insight to be drawn from Calabresi's argument is a negative one: the majoritarian position cannot object to dynamic statutory interpretation unless it appears that the original majority which sought enactment, and had a discernible intent on the interpretive issue, persists. Of course, this is all but impossible to demonstrate. Where societal and legal circumstances have decisively changed since the enactment of the original statute, there is usually good reason to believe that the historical majority has vanished. ${ }^{190}$

A third response, not explored by Calabresi, justifies dynamic statutory interpretation in cases like Weber, where it is likely that the majority will has not changed. This response challenges the primacy that traditional legal process thinkers have given to the countermajoritarian difficulty. While it is routinely assumed by scholars such as Calabresi that our society is committed to majoritarian government, this is only true in the most general sense. Notwithstanding the one-person, onevote cases, political gerrymandering and other devices ensure that elections will not reflect true majority preference. ${ }^{101}$ Once these representa-

187 For example, most Americans still seem to identify with the plight of Brian Weber, the white male who did not get into the training program because of affirmative action, and they have no sympathy for the prisoner in Smith $v$. Wade who wanted punitive damages for harm caused him while in prison.

188 See Brest, Interpretation and Interest, 34 STAN. L. REv. 765, $770-73$ (1982).

188 See Sunstein, Legal Interference with Private Preferences, 53 U. CHI. L. REv. $1129,1145-58$ (1986).

190 Two caveats exist to this argument. One is that there are occasions where changed circumstances very probably have not changed popular attitudes-the Weber case is a good example. See supra note 178. Another is that typically the result will be one of double indeterminacy: the intentionalist interpreter will not be able to prove that the original majority persists, while the dynamic interpreter will not be able to prove that subsequent developments represent a new majority will.

181 The issues in the leading case, Davis v. Bandemer, 106 S. Ct. 2797, 2810-11 (1986) (stating that disproportionate representation is not in itself discrimination and is therefore not prima facia unconstitutional), are analyzed in Symposia: Gerrymandering and the Courts, 33 UCLA L. Rev. 1 (1986). See also Note, The Constitutional Imperative of Proportional Representation, 94 YALE L.J. 163, 165, 172-75 (1984) (grounding objection to a lesser degree of protection against gerrymandering in a belief that "[p]roportional representation is the only system that fully achieves the underlying 
tives are in office, public choice theory predicts that their incentives will lead them away from majoritarian preferences and that, in any event, the rules created by a legislature will often fail to reflect majority preferences because of procedural manipulations. ${ }^{192}$ In fact, there is a lively but controversial line of neo-Beardian scholarship which argues that the Constitution is either antimajoritarian or, at least, represents a limited democracy in which majoritarian preferences are not automatically reflected in legislative results. ${ }^{193}$

Had the Framers favored, and the Constitution embodied, a strict majoritarianism, the system of "direct democracy," in which people vote on statutory proposals, might have been appropriate. Yet direct democracy was considered and rejected in favor of representative democracy. A Madisonian vision of the Constitution explains this result and suggests that the deliberative process of lawmaking seeks to transform private preferences, not just reflect them. ${ }^{194}$ Madison's Federalist No. 10 is the best exposition of this reasoning: the main danger of a direct democracy is that temporary majorities might enact laws which are unjust to the minority and not in the public interest. ${ }^{195}$ Structurally, a representative government better protects against this danger because it is able "to refine and enlarge the public views by passing them through the medium of a chosen body of citizens, whose wisdom may best discern the true interest of their country, and whose patriotism and love of justice will be least likely to sacrifice it to temporary or partial considerations." ${ }^{196}$ Madison claimed that "it may well happen that the public voice, pronounced by representatives of the people, will be more consonant to the public good than if pronounced by the people themselves."197

value of majority rule and minority representation").

192 See generally K. Arrow, Social Choice and Indrvidual Values (2d ed. 1963); D. Black, The Theory of Committees and Elections 21-22, 51 (1963) (discussing procedure and its effect on preference voting); T. Sullivan, Procedural STRUCTURE: SUCCESS AND INFLUence IN Congress 2 (1984) (illustrating that "decisions made about procedures often determine the substance of the policy question"); W. RIKER, Liberalism Against Populism 66-115, 138-196 (1983) (discussing the dilution of majority preference by offering voting alternatives, permitting strategic voting, or controlling the agenda). See also Parker, supra note 14, at 239-46 (stating that because most voters are passive and manipulated, the asserted majoritarian basis for legislative supremacy is questionable).

193 See M. Parenti, Democracy For the Few 49-55, 193-207 (1977); Parenti, The Constitution as an Elitist Document, in How Democratic Is THE ConstituTION? 39, 58 (R. Goldwin \& W. Schambra eds. 1980).

${ }_{104}$ See Ackerman, Beyond Carolene Products, 98 HARv. L. Rev. 713, 740-44 (1985); Sunstein, supra note 189, at 1134-35.

${ }_{105}$ The Federalist No. 10 (J. Madison) (C. Rossiter ed. 1961).

196 Id. at 82.

${ }^{207}$ Id.; see also The Federalist No. 62 (J. Madison) (C. Rossiter ed. 1961) 
The deliberative democracy envisioned by the Framers, therefore, is one in which "the public voice" will speak beyond the private preferences of citizens. The Givil Rights Act of 1964, for example, was a great statute not only because it embodied a fundamental public value, but because the process of educating the American people both before and after enactment transformed private values as well. ${ }^{188}$ Likewise, Weber and other cases interpreting Title VII dynamically are part of the deliberative process by which this public voice speaks to new circumstances. Even Bickel, the popularizer of the countermajoritarian difficulty with judicial review, admitted that our society's general commitment to majoritarianism is not absolute, for our political history reveals an equally important commitment to "a system of enduring basic values," or national ideals. ${ }^{199}$

In short, under this third response, the Constitution seems to envision a dynamic policy creation in which majoritarian preferences are filtered and transformed through the deliberations of their representatives. In Congress, the preferences of members of the House, the most accountable representatives, are tempered by further deliberation by members of the Senate, the less accountable representatives, who originally were not even popularly elected. ${ }^{200}$ The role of the courts, therefore, is to be further deliberative filters, as envisioned by Hamilton, mitigating the effects of unwise laws and exploring their full consequences. ${ }^{201}$ Under this more complex view of the countermajoritarian difficulty, dynamic statutory interpretation is not problematic unless courts are not appropriate representatives or are not accountable for their mistakes. The remainder of this part addresses these issues.

\section{Dynamic Statutory Interpretation's Contribution to the Overall Legitimacy of Government}

Writing in the Madisonian tradition, Hanna Pitkin's The Concept

(similar argument in defense of our bicameral legislature, emphasizing that the Senate, which was not to be popularly elected, could provide seasoned deliberation to temper the majoritarian impulses of the House).

198 See Sunstein, supra note 189 , at 1130 \& n.5.

199 A. BICKEL, supra note 171 , at 51 ; see also id. at $27-28$ (leaving open the question whether we may want a system of government that, on occasion, imposes a principle upon a "consistent and determined majority"); M. PerRy, The ConstituTION, THE COURTS AND HuMAN RIGHTS: AN INQUIRY INTO THE LEGITIMACY OF Constitutional Policymaking 146-62 (1982) (applauding judicial activism that leads to protection of those whose political voice is muted, even if the political process were to "persist in transgressing the human rights declared by the court").

200 Until 1913, when the seventeenth amendment was ratified, each state legislature selected the state's U.S. senators. U.S. ConsT. amend. XVII, $\S 1$.

201 The Federalist No. 78, at 467 (A. Hamilton) (C. Rossiter ed. 1961). 
of Representation explores the basis for the legitimacy of representative democratic government. She starts with a functional, rather than populist or majoritarian, vision of representatives: "Their role . . . is to speak for, act for, look after the interests of their respective groups. ... [T]he test of representation is not whether the leader is elected, but how well he acts to further the objectives of those he represents." ${ }^{202}$ How the representative acts counts for more than how the representative is chosen. Pitkin posits that government is legitimate "not by demonstrating its control over its subjects but just the reverse, by demonstrating that its subjects have control over what it does. . . . A representative government must not merely be in control, not merely promote the public interest, but also be responsive to the people."203 The lessons of Pitkin's scholarship are that representative government is most legitimate when it is responsive to the ongoing needs and problems of the community, and that "representatives" of the people need not all be popularly elected in a functioning democracy. Indeed, given the biases of the political process, the fact that judges are not elected may enable them to be better "representatives" of the people than their elected legislators are (in some instances). At the very least, judicial lawmaking through dynamic statutory interpretation can contribute to the overall legitimacy of government.

Both public choice theory and institutional process theory suggest that the legislature acting alone will be subject to three biases which undermine the overall legitimacy of government: failure to enact or update public interest laws, avoidance of hard choices, and favoritism directed at power groups. These biases may be ameliorated by treating judges as representatives charged with interpreting statutes dynamically. The first of these biases is legislative inattention to laws benefiting the public, including failure to amend the few such laws enacted to reflect new circumstances. ${ }^{204}$ Public choice theory calls these "distributed benefit laws" and posits that such laws will not often be enacted, because they rarely stimulate the formation of supportive interest groups and because they offer few opportunities for legislators to advance their reelection chances. ${ }^{205}$

Institutional process theorists similarly argue that legislative policy does not address public problems in an integrated and timely man-

202 H. Pitkin, The Concept of Representation 116 (1967) (discussing the role of a member of an appointed administrative board designated to represent labor interests).

${ }^{203} I d$. at 232.

204 See M. Fiorina, supra note 154 , at $40-49$.

205 See supra text accompanying notes 153-57. 
ner. ${ }^{208}$ The increasingly decentralized structure of Congress has resulted in problems of coordination and leadership that threaten the ability of Congress to be responsive to changing policy concerns. ${ }^{207}$ The many procedural obstacles to statute creation-the bicameralism requirement, committee scrutiny, procedural gambits and delays, and the limited agenda of the legislature-make legislative policy creation an adventitious occurrence. Thus, Professor John Kingdon has characterized the legislative process as "garbage can decisionmaking."208 Under this vision of the legislative process, Congress is an "organized anarchy," which only passes statutes when a problem becomes politically salient at a time when a well-considered solution is available and the political climate is ripe for change. This confluence of publicized problem, feasible solution, and political opportunity is to some extent adventitious. While institutional process theorists have more faith than public choice theorists that Congress seeks the common good, the institutional process theory suggests that Congress does not, and cannot, perform that important function very often. Instead, Congress will rarely return to general interest statutes to revise them in light of changed circumstances.

Courts can counteract the effect of legislative inattention to general public interests by interpreting statutes dynamically as the statutes grow older. Section 1983 is an example of this phenomenon. Because it was originally enacted as a response to officially sanctioned Southern discrimination against blacks, section 1983 became obsolete when the problem changed, that is, when state officials acted more discreetly, avoiding easy-to-spot discriminatory laws. As a result of the lack of legislative revision, the Supreme Court revived the statute in 1961 simply by reinterpreting it in light of new, but equally real, forms of official oppression. ${ }^{209}$ Since then, the Court has filled in most of the details of the generally worded statute (as it did in Smith $v$. Wade) and has provided an efficacious but flexible scheme for effectuating important

208 See, e.g., A MATter of Principle, supra note 10, at 321-23 (depicting the legislative process as one characterized by an inherent lack of consensus and direction); see also infra notes 214-16 and accompanying text.

207 Dodd, Congress, the Constitution, and the Crisis of Legitimation, in CoNGRESS RECONSIDERED 401-405 (L. Dodd \& B. Oppenheimer eds. 1977) (discussing the gradual shift of power to subcommittees during the 1960's and 1970's and suggesting that this shift will ultimately inhibit congressional response to changing conditions).

${ }^{208} \mathrm{~J}$. KingDon, supra note 147 , at $48-74$ relying on Cohen, March \& Olsen, $A$ Garbage Can Model of Organizational Choice, 17 ADMIN. ScI. Q. 1 (1972)).

${ }_{209}$ Monroe v. Pape, 365 U.S. 167, 174-80 (1961) (holding that the language of section 1983 does not exclude actions by a policeman who can show no authority under state law, custom, or usage to do what he did), overruled on other grounds, Monell v. New York City Dep't of Social Servs., 436 U.S. 658, 701 (1978). 
rights. Little of this would have been achieved through the legislative process alone.

The other two biases of legislative policymaking are its tendency to avoid or defer hard political choices, resulting in fragmented policy, and its tendency covertly and subtly to distribute advantages to a favored group, resulting in unfair policy. ${ }^{210}$ Public choice theory posits that Congress will avoid conflictual demand patterns by means of three strategies. ${ }^{211}$ First, Congress may delegate hard political choices to agencies, which are often "captured" by the regulated interests. Second, the legislature may ratify a compromise acceptable to the relevant interest groups. Third, and most subtly, Congress may adopt evasive strategies, such as leaving key terms ambiguous or conveniently obscuring the nature of an interest group's distribution behind the veil of some stated public purpose. The cumulative effect of these three strategies is that favored interest groups may profit at the expense of the public and that policy becomes a congeries of ad hoc compromises.

A similar view is espoused by institutional process theorists. ${ }^{212}$ Congress tends to be decentralized much, if not most, of the time, thereby encouraging routine policymaking by "subgovernments" consisting of subcommittee members, bureaucrats, and lobbyists interested in the particular issue. ${ }^{213}$ "Routine" legislation is legislation in which the President, Congress, and the political parties do not become actively involved and is generally controlled by these subgovernments pushing government policy toward distributions for favored interests. More publicized legislation will often reflect compromises with these subgroups and delegation of future lawmaking responsibilities to them.

This process, in which Congress defers policy choices or secretly distributes benefits to organized groups, does little to contribute to the legitimacy of our government. Courts cannot, under conventional constitutional theory, invalidate such interest group arrangements, but they can at least inject a dynamic deliberative process into statutes that avoid or hide tough policy choices. For example, Congress avoided many con-

210 See H. PIrkin, supra note 202, at 219-21.

213 See supra text accompanying notes 153-57.

212 See, e.g., R. Davidson \& W. Oleszek, Congress and Its Members 42329 (2d ed. 1985) (arguing that structural policies are made in subcommittees and that Congress is as concerned with how it looks to its constituents as it is with the substance of created law); R. Ripley \& G. Franklin, Congress, THE Bureaucracy and Public Policy 6-10, 13-28 (4th ed. 1987) (stating that the complexity of federal policymaking leads to delegation of power where Congress "allows the executive branch freedom to specify policy content of legislation"); R. RIPLEY, CoNGREsS: Process AND Policy 4-22 (1977) (discussing the congressional committee system and delegation of power to administrators).

${ }^{213}$ See R. Ripley \& G. FrankLin, supra note 212 , at 8-11. 
troversial questions by refusing to define "discriminate" in Title VII; yet the Court continued the deliberative process, as it were, in Weber. ${ }^{214}$ However, where Congress explicitly has set bounds to protect certain interests, such as protecting seniority systems as it did in Stotts, ${ }^{215}$ it is proper for the Court to respect those limits. Likewise, when Congress has delegated rulemaking power to administrators, it is they who will interpret the statute dynamically, but the Court's role is to assure that they do so through a deliberative process which is broadly responsive to the common good. ${ }^{216}$

There appears to be substantial scholarly and experiential evidence that statutes produced by Congress often do not sufficiently address the general needs of the citizenry and, when they do, do not make the hard policy choices. These phenomena make policy susceptible to obsolescence and interest group bias, that is, not a system of representative government responsive to the needs of its constituency. A judiciary that always faithfully interprets such statutes according to the original intent is not contributing to the legitimacy of our government as a whole. A model of dynamic statutory interpretation would contribute somewhat to the judiciary's positive role in our representative democracy, because it would help to ameliorate some of the biases attendant to the legislative process.

\section{Courts Are Institutionally Competent to Perform the Lawmaking Role Implicit in the Task of Dynamic Statutory Interpretation}

When circumstances have significantly changed and the statutory text is indeterminate, the countermajoritarian difficulty fails to provide a sufficient basis to deny courts the power to interpret statutes dynamically. Indeed, dynamic interpretation may contribute to the overall legitimacy of government. However, a central concern remains unaddressed: whether judges can be entrusted with this sort of lawmaking.

214443 U.S. 193, 204-09 (1979) (holding that a race-conscious statute is not necessarily discriminatory where it is narrowly tailored to redress past discrimination).

218467 U.S. 561, 576-81 (1984).

${ }_{218}$ See Motor Vehicle Mfrs. Ass'n v. State Farm Mut. Ins. Co., 463 U.S. 29, 5157 (1983) (objecting to the National Highway Traffic Safety Administration's rescission of its newly adopted passive restraint requirement for the manufacture of new cars); Bill Johnson's Restaurants, Inc. v. NLRB, 461 U.S. 731, 748-49 (1983) (limiting NLRB power to seek cease and desist order against a state court lawsuit); Greater Boston Television Corp. v. FCC, 444 F.2d 841, 850-53 (D.C. Cir. 1970) (leading case for the "hard-look" doctrine); Sunstein, Deregulation and the Hard-Look Doctrine, 1983 SuP. CT. REv. 177, 181-84, 206-13 (examining the hard-look doctrine under which courts review the reasonableness of an agency's exercise of its rulemaking discretion). 
It is questionable whether it is proper that value choices made by nonelected judges displace choices made by elected legislators. The specter of Dred Scott ${ }^{217}$ and Lochner ${ }^{218}$ and other past misjudgments raise doubts about any theory that openly accepts this type of judicial lawmaking.

These charges, that courts are incompetent to perform implicit lawmaking, are entirely overstated for three reasons. First, our polity already gives enormous lawmaking power to administrative agencies. ${ }^{219}$ In a vast range of statutes, agencies are empowered to update ongoing policy, often with virtually no congressional standards to confine administrative discretion. ${ }^{220}$ Although an agency's choice of policy is subject to judicial review, courts typically uphold an agency's choice when it is not contrary to the text of the statute and is reached after a deliberative process. ${ }^{221}$ Moreover, bureaucrats, like judges, are not elected. To give them power to update statutes seems no more legitimate than to recognize a similar power in judges. If anything, judges who update statutes are more trustworthy. They are not only removed from the political process but are also in positions that give them few incentives to slant their interpretations, as bureaucrats often do, in favor of regulated groups. ${ }^{222}$

217 Dred Scott v. Sandford, 60 U.S. (19 How.) 393 (1856).

218 Lochner v. New York, 198 U.S. 45 (1905).

219 See Administrative Procedure Act, 5 U.S.C. $\S \S 500-73$ (1982).

220 Note here the disuse at the federal level of the old "nondelegation doctrine," which required Congress to set forth intelligible standards in statutes delegating responsibilities to agencies so that the agency-implemented policy would ultimately be governed by majority rule. Compare Schechter Poultry Co. v. United States, 295 U.S. 495, 529-30 (1935) (final use of nondelegation doctrine by the Court to strike down a federal law) with Yakus v. United States, 321 U.S. 414, 425 (1944) (upholding delegation to the Office of Price Administration of power to control prices during World War II, the only standard being that prices be "fair and equitable") and Amalgamated Meat Cutters \& Butcher Workmen v. Connally, 337 F. Supp. 737, 745 (D.D.C. 1971) (upholding an unbridled delegation to President to stabilize "prices, rents, wages and salaries" without even a mention of the "fair and equitable" standard).

${ }^{221}$ See Chevron U.S.A., Inc. v. Natural Resource Defense Council, 467 U.S. 837, 842-45 (1984) (upholding the Environmental Protection Agency's definition of "statutory sources"); Udall.v. Tallman, 380 U.S. 1, 16 (1965) (upholding the Secretary of Interior's interpretation of law pertaining to disposition of public land); Diver, Statutory Interpretation in the Administrative State, 133 U. PA. L. REv. 549, 559-67 (1985) (discussing judicial deference to administrative statutory interpretation).

${ }_{222}$ See Parker, supra note 14, at 243-44. It may appear anomalous that bureaucrats, who are theoretically responsible to the President in most cases, should be unresponsive to the national public interest. But the public choice literature suggests that theoretical responsibility will matter little compared to interest group pressure, and common experience confirms this insight. See M. BERnstein, Regulating Business BY INDEPENDENT COMMISSION 126-63 (1955) (discussing agencies in terms of independence, responsibility, and the public interest); Posner, The Federal Trade Commission, 37 U. CHI. L. REv. 47, 82-89 (1969) (discussing causes of regulatory failure at the Federal Trade Commission). 
Second, judges can be trusted with greater discretion. Our polity already gives much broader lawmaking power to judges in nonstatutory situations than the power I advocate here for statutory interpretation. A good example of this judicial discretion is structural injunction litigation, in which courts preside over the reconstruction of public or private institutions. ${ }^{223}$ Although critics have decried structural injunctions as judicial "usurpation" of legislative and executive power, ${ }^{224}$ Professor Owen Fiss and other defenders of the structural injunction have carefully justified the legitimacy of this type of judicial lawmaking. ${ }^{22 s}$

According to its supporters, structural litigation is justified because, substantively, it contributes to our society's need for social justice and public values ${ }^{226}$ and because, procedurally, it reveals that judges are much better at policy creation than traditionally supposed. ${ }^{227}$ In structural litigation, the old bromides extolling judicial independence from political pressures and the professional ideal of reflective and dispassionate analysis of focused problems have been demonstrated in the most trying circumstances in which judges are tempted to become personally involved in their cases. For example, Fiss's case study of the Arkansas Prison Litigation reveals that at the center of the litigation was a cautious, although not otherwise celebrated, judge whose judicious style created a detailed new legal regime for the prison system and, if anything, enhanced our respect for the judiciary. ${ }^{228}$ Moreover, judges in structural litigation have been superior gatherers of information through adversary presentations and testimony at judicial hearings, the appointment of special masters, the submission of studies by experts, and so forth. ${ }^{229}$ Indeed, the nonbureaucratic nature of the judiciary has had some advantages. Unlike bureaucrats, judges must deliberate about problems brought before them; they cannot simply ignore problems. Also unlike bureaucrats, judges make law in the context of

${ }^{223}$ An example of a public institution under reconstruction is a school district undergoing court-imposed integration. See O. Fiss, ThE Givil Rights InJunction 16 (1978).

224 See, e.g., L. Graglia, Disaster by Decree 258-83 (1976) (describing the Supreme Court's attempt to compel integration as self-defeating); see also R. BERGER, Government BY JUdiciary 351-62 (1977) (discussing legitimacy of judicial review under the fourteenth amendment).

${ }^{225}$ See O. Fiss, supra note 223, at 9-12, 93-95; O. Fiss \& D. Rendleman, Injunctions 528-30 (2d ed. 1984); Chayes; The Role of the Judge in Public Law Litigation, 89 HARv. L. REv. 1281, 1288-1316 (1976) (discussing, with approval, legitimacy of judicial actions under the public law litigation model).

${ }^{226}$ Fiss, The Supreme Court, 1978 Term-Foreword: The Forms of Justice, 93

HaRv. L. REv. 1, 2 (1979).

${ }^{227}$ See Chayes, supra note 225, at 1313-16.

228 O. Fiss \& D. Rendelman, supra note 225, at 529-752.

220 See O. Fiss, supra note 223 , at $34,54-58$. 
specific fact situations, thereby enabling them to focus their policy and to change it incrementally.

The first two responses to concerns about judicial imposition of personal values have an analogical appeal: if we allow lawmaking by agencies in statutory matters and by courts in nonstatutory matters, we should allow lawmaking by courts in statutory matters. The third response is that the adjudicative process will minimize the imposition of values idiosyncratic to individual jurists, because it is incremental and conventional. ${ }^{230}$ Consider the process by which the Supreme Court came to interpret section 1983 when it found municipalities liable for civil rights violations. ${ }^{291}$ The Court's original view that municipalities could not be sued under section 1983 was subjected to unfriendly critical scrutiny ${ }^{232}$ and even lower court evasion ${ }^{233}$ - thereby justifying the Court's reconsideration of the issue in $1978 .{ }^{234}$ Indeed, the interpretive process continues, inevitably influenced by the courts' continuing experience with section 1983. ${ }^{236}$ If the specific language in section $1983 \mathrm{had}$ excluded municipal liability, the issue would not have been the object of litigation, and proponents of municipal liability would have taken their case to the legislature. If the issue had not been a relatively important societal concern, it probably would not have been litigated extensively

230 See generally S. BuRTON, supra note 116, at 191-92, 199-215 (discussing legitimacy of adjudication and alternatives to formalism, including conventionalism); Fiss, Conventionalism, 58 S. CAL. L. REv. 177, 183-96 (1985) (discussing sources of constraint on the interpretive process including professional norms); Fiss, Objectivity and Interpretation, 34 STAN. L. REV. 739 (1982) (arguing that adjudication can be both interpretive and objective).

231 In the 1950's, there were few suits under $\$ 1983$. The Court substantially expanded the scope of $\S 1983$ in Monroe v. Pape, 365 U.S. 167, 187-92 (1961), by holding that the state action need not have been sanctioned by state law. The Court also held, however, that municipalities were immune under the statute. Finally, in Monell v. New York City Dep't of Social Servs., 436 U.S. 658, 690 (1978), the Court held that municipalities could be sued under certain circumstances.

${ }_{232}$ See, e.g., Note, Accountability for Govermment Misconduct: Limiting Qualified Immunity and the Good Faith Defense, 49 TEMP. L.Q. 938, 971-79 (1976) (arguing that Monroe $v$. Pape should be overruled and that municipalities should be liable for section 1983 violations).

${ }_{238}$ See e.g., Brault v. Town of Milton, 527 F.2d 730, 735 (2d Cir. 1975) (en banc) (holding that although a municipality is not a "person" for the purposes of section 1983, the fourteenth amendment itself may give rise to a cause of action); Fitzgerald v. Porter Memorial Hosp., 523 F.2d 716, 718 n.7 (7th Cir. 1975) (noting that a municipal hospital may be sued directly under the fourteenth amendment), cert. denied, 425 U.S. 916 (1976).

${ }^{234}$ Monell v. New York City Dep't of Social Servs., 436 U.S. 658 (1978).

235 Tarantino v. North Carolina, 639 F. Supp. 661, 670-71 (W.D.N.C. 1986) (detective's decision to search is not policy for the purposes of section 1983); Hornung v. Village of Park Forest, 634 F. Supp. 540, 545-46 (N.D. Ill. 1986) (elaborating on pleading requirements necessary to state a $\S 1983$ claim against a municipality); Kime v. Wise, 634 F. Supp. 514, 515-17 (N.D. Ohio 1985) (distinguishing official municipal policy or custom from an isolated act). 
enough to reach the Supreme Court or, if it reached the Court, it might not have been decided on the merits. Just as the common law is built by slow case-by-case adjudication, the evolution of statutory common law proceeds over an extended period of time, as courts build carefully on their prior experience with the statute. The slowness and deliberateness of judicial lawmaking ensures that it will never be a threat to legislated lawmaking as the main source of policy preference and priorities in the United States.

The judge's interpretation will not be idiosyncratic, moreover, because it must be justified by a written opinion which relies on sources other than the judge's personal values. Although judges can find reasons and facts to support a variety of interpretations, their professional reputations depend in part on the persuasiveness of their justifications to readers with different values. ${ }^{236}$ Adjudication has been likened to an extended legal conversation, in which the interpreter is both constrained and legitimated by her need to explain and justify her interpretations to the interpretive community of other jurists, legislators, scholars, and lawyers. ${ }^{237}$

While the traditional legitimacy concerns about judicial lawmaking seem to be misplaced when applied against the cautious dynamic statutory interpretation model posed in this article, a nontraditional legitimacy concern is more troublesome. Professor (now Dean) Paul Brest argues that lawyers are social and economic elites who are less representative of society as a whole than the mix of lawyers and nonlawyers found in Congress. ${ }^{238}$ The implication of Brest's argument is that any defense of judicial lawmaking which appeals to the regulatory effects of the legal interpretive community may be socially questionable.

The legal process response to Brest's observation has been to invoke the commitment of the legal community to such things as "order and justice" and "legal reasoning in bringing these values and principles to bear in particular cases." 239 This response is not completely satisfying, because so many lawyers, and too many judges, seem only perfunctorily committed to these values, and because there appear to be structural biases in adjudication that favor established interests. ${ }^{240}$

236 See S. BURTON, supra note 116, at 211.

287 See id. at 210-14.

298 See Brest, supra note 188 , at $770-73$.

239 S. BuRTON, supra note 116, at 209; see Fiss, Objectivity and Interpretation, supra note 230.

240 See generally Galanter, Why the "Haves" Come Out Ahead: Speculations on the Limits of Legal Change, 9 L. \& Soc'y REv. 95 (1974) (noting the advantages "repeat players"-i.e., insurance companies, prosecutors, and finance companies-have 
Nonetheless, Brest's concern, while important, is no reason to reject dynamic interpretation of statutes by judges, since traditional interpretation tends to ossify the status quo, which makes it more protective of established elites.

\section{Dynamic StatuToRy INTERPRETATION APPLIED}

Theoretically, my model of dynamic statutory interpretation offers quite a different focus from traditional theories of statutory interpretation because it treats the evolutive context as a persuasive source of statutory meaning which should be considered in addition to the statute's text and legislative history. Thus far in the Article, I have set forth the theoretical basis for the model and defended the model against the main academic objections. In this final Part, I will illustrate the operation of my cautious model of dynamic interpretation, while at the same time contrasting it to the intentionalist and modified intentionalist approaches often invoked by the Supreme Court and to Dworkin's recent (and obviously related) theory of statutory interpretation. One goal of this Part is to suggest that the model represents a better methodology for the Court's statutory interpretation cases than the other theories.

I do not argue that the model of dynamic statutory interpretation will produce different results in a large number of cases. After all, as literary theory teaches us, the current context and public values always exercise some influence on the interpretive enterprise. Instead, the model is appealing because it rests upon a realistic vision of the legislative and interpretive processes and because it promotes more candid decisionmaking in statutory interpretation cases. Just as dynamic statutory interpretation provides a more illuminating and defensible basis for the results in Weber and Smith $v$. Wade, so it does for many of the Court's other decisions. It further provides a realistic framework for pursuing Dworkin's suggestion that statutory interpretation looks to the life as well as the history of statutes.

\section{A. Dynamic Interpretation and the Intentionalist Mythology}

The intentionalist approach to statutory interpretation employed by the majority and primary dissenting opinions in Smith $v$. Wade and the dissenting opinion in Weber has severe disadvantages. It relies on a psychological construct, legislative "intent," in which very few scholars

over "one-shotters"-i.e., auto-injury claimants, criminal defendants, and spouses in divorce proceedings-in litigation). 
still believe, ${ }^{241}$ and focuses on sometimes indeterminate, but more often irrelevant, arcana. My dynamic model of statutory interpretation is preferable to the intentionalist mythology because it is theoretically more consistent with modern ideas about interpretation and law, and because it concentrates the courts' and the parties' attention on the truly relevant factors. I do not claim that my approach is always easier to apply or even that it always yields more determinate answers in the hard cases of statutory interpretation. I only claim that it focuses on the appropriate considerations-those which actually influence and ought to influence the Supreme Court's interpretation of statutes all the time.

The contrast can be illustrated by comparing Smith $v$. Wade with the Supreme Court's earlier interpretation of section 1983 in Pierson v. Ray. ${ }^{242}$ In Pierson, the Court considered whether state judges enjoy absolute immunity from section 1983 lawsuits arising out of their judicial duties. In a brief and unadorned opinion, the Court examined the history of section 1983 and the common law doctrine of judicial immunity. Given the strong historical and continuing policy behind judicial immunity ${ }^{243}$ and insufficient reason to think that section 1983 lawsuits against judges were necessary to protect civil rights, the Court held judges immune from section 1983 lawsuits. ${ }^{244}$ The Court's opinion has a simple persuasiveness, in part because it rested on a common-sense, widely-accepted current policy of judicial immunity, but also because it glided over the complex question of how Congress in 1871 would have answered the question. Although the dissenting opinion in Pierson argued persuasively that Congress in 1871 expected judges to be sued under section 1983, ${ }^{248}$ the changes in society and law since 1871 (and the strong policy favoring judicial immunity) render such historical perspective largely irrelevant. The original legislative expectation that judges could be sued rested upon the apparent widespread conspiracy of state judges to suppress the rights of blacks in the South during the Reconstruction. ${ }^{246}$ Were such a conspiracy still in existence, the presumption of judicial immunity might be abrogated. As the Pierson Court implicitly recognized, however, there is no evidence that the modern state judiciary should not receive the accustommed judicial immunity in civil rights cases.

For an old, generally worded statute that has been the subject of

241 See scholars cited supra note 116.

242386 U.S. 547 (1967).

243 Id. at 553-54.

24 Id. at 554-55.

245 See id. at 559, 561-63 (Douglas, J., dissenting).

${ }^{246}$ See id. at 559-60 (Douglas, J., dissenting). 
much litigation, the original legislative expectations actually carry very little weight in the interpretive process, whatever rhetoric the Court uses to justify its result. This is a lesson of the section 1983 cases-both Pierson v. Ray (where the Court openly read the statute to reflect current, rather than historical, policy preferences) and Smith $v$. Wade (where the Court purported to conduct a historical inquiry, but was probably reading the statute dynamically). ${ }^{247}$ Of course, when the statutory scheme is more detailed and more recent, the original legislative expectations play a greater role in my model. As the following case suggests, however, these expectations should not always be determinative.

In Morrison-Knudsen Construction Co. v. Director, Office of Workers' Compensation Programs, ${ }^{248}$ the Court considered whether employer contributions to union trust funds for pensions are "wages" for the purposes of computing compensation benefits under section 2(13) of the Longshoremen's and Harbor Workers' Compensation Act of 1927 (LHWCA). ${ }^{248}$ At that time, section 902(13) defined wages as "the money rate at which the service rendered is recompensed under the contract of hiring in force at the time of the injury, including the reasonable value of board, rent, housing, lodging, or similar advantage received from the employer."250 The District of Columbia Circuit

${ }^{247}$ For another example of these approaches, see Briscoe v. LaHue, 460 U.S. 325 (1983). In Briscoe, the majority opinion relied mainly on current policy and common law doctrine to grant police officers witness immunity in a $\$ 1983$ lawsuit, while the dissenting opinion engaged in an excellent but irrelevant historical analysis of legislative expectations concerning witness immunity in 1871. There are many other examples. See, e.g., Memphis Community School Dist. v. Stachura, 106 S. Ct. 2537 (1986) (relying on doctrines of common law torts to overturn $\S 1983$ damage award based on the abstract value or importance of constitutional rights); Pembaur v. City of Cincinnati, 106 S. Ct. 1292, 1302 \& n.1 (1986) (Stevens, J., concurring) (noting that the decision rests on policy grounds); Wilson v. Garcia, 471 U.S. 261 (1985) (using current practical policy considerations in interpreting $\S 1983$ with regard to aplicable statute of limitations); Tower v. Glover, 467 U.S. 914 (1984) (relying on lack of common law evidence supporting $\S 1983$ immunity for public defenders, but rejecting current policy argument); Pulliam v. Allen, 466 U.S. 522 (1984) (rejecting $\$ 1983$ immunity for state magistrate because not supported by common law doctrine); Forrester v. White, 792 F.2d 647 (7th Cir. 1986) (examining state law to determine the scope of judicial authority and allowing $\S 1983$ immunity for a judge charged with sex discrimination in the discharge of a probation officer), cert. granted, $107 \mathrm{~S}$. Ct. 1285 (1987). Much the same demonstration could be made for the Court's interpretation of the Sherman Act, the habeas corpus statute, $\S 10(\mathrm{~b})$ of the Securities Act, $\S 504$ of the Rehabilitation Act, and several other common law statutes.

248461 U.S. 624 (1983).

24833 U.S.C. $\$ 901-950$ (1982 \& Supp. III 1985).

28033 U.S.C. $\$ 902(13)$ (1982). Following this lawsuit the statute was amended and now specifically excludes such fringe benefits as employer payments to pension funds. See Longshore and Harbor Workers' Compensation Act Amendments of 1984, Pub. L. No. 98-426, § 2, 98 Stat. 1639, 1640 (codified at 33 U.S.C. § 902(13) (Supp. 
Court of Appeals held that contributions to pension funds are a "similar advantage" to "board, rent, housing, [and] lodging" and so should be included in calculating compensation benefits. ${ }^{261}$ The Supreme Court, with only one Justice dissenting, rejected this interpretation, citing three principal reasons. First, the plain language of the statute suggested to the Court that contributions to employee pension, health, and welfare plans were not "similar" to board, rent, and lodging. The latter are "benefits with a present value that can be readily converted into a cash equivalent on the basis of their market values," while the former are contingent upon the employee's working for a certain time and so are speculative in value. ${ }^{252}$ Second, Congress could not have intended to include employer-funded pension benefits because they were all but unknown in $1927 .{ }^{263}$ Third, the Court relied on the long practice of the Director of Workers' Compensation not to include fringe benefits in the definition of wages. $^{254}$

While this case is a close one, interpreting the statute dynamically might suggest a different analysis. The statutory text is hardly determinative because the "similar advantage" language invites the courts or the agency to update the statute as new "advantages" are given to workers. The Court is surely correct in observing that the original legislative expectation was that pension benefits were not included, but the weight of those original expectations is reduced by a material change in societal circumstances, the dramatic growth of fringe benefits as a significant portion of the employee's total compensation package. ${ }^{255}$ The contingent nature of pension benefits does not obscure the fact that they are the functional equivalent of direct payments and that, like direct payments, they have a determinable present value. ${ }^{258}$ Because Congress

III 1985)).

${ }_{251}$ Hilyer v. Morrison-Knudsen Constr. Co., 670 F.2d 208 (1981), rev'd sub nom. Morrison-Knudsen Constr. Co. v. Director, Office of Workers' Compensation Programs, 461 U.S. 624 (1983).

${ }_{252} 461$ U.S. at $630-31$.

253 Id. at 632. The Court also noted that Congress had amended the statute twice since 1927 without changing the definition of "wages," and that Congress had in 1964 amended the definition of wages in the Davis-Bacon Act to include fringe benefits, in order to bring the statutory definition "into conformity with modern wage practices." Id. at 632-33.

${ }^{254} I d$. at 634-35. This argument was undercut by the fact that the Director changed his mind in the course of the litigation and submitted a brief in the lower court arguing that the traditional agency position was wrong. See id. at 645-46 (Marshall, J., dissenting).

${ }_{258}$ Today, fringe benefits are estimated to comprise about $15 \%$ of employers' compensation costs, and this figure is expected to rise to $33 \%$ by the year 2050 . See id. at 641 (Marshall, J., dissenting).

${ }_{2 s 8}$ Justice Marshall's dissenting opinion observed that in the instances where Congress or the relevant agencies had changed compensation statutes to include fringe 
had not specifically focused on the exact ambit of "wages" when it passed the statute or amended it thereafter, there is no political compromise that should be enforced on this issue. In fact, the agency began thinking seriously about the issue only six years before the Court's opinion-and the Director had submitted a brief in the proceedings below, arguing that the traditional position was wrong. ${ }^{257}$

Even where, as in Morrison-Knudsen, the original legislative expectations are relevant, dynamic interpretation differs from a static approach by refusing to stop with the original legislative understanding, unless that understanding is clearly grafted onto the statutory language. The interpretation reading pension benefits into the definition of wages is probably the fairest interpretation in light of current policy. Indeed, it is arguably more faithful to the original "deal" than the Court's interpretation, which cuts off important benefits workers now receive. This underlines a deeper problem with the intentionalist rhetoric often used by the Court. Although there are few cases like Morrison-Knudsen due to the Court's adherence to a cautiously dynamic approach to middle-aged and relatively detailed statutes such as the LHWCA, ${ }^{258}$ the rhetorical focus of the parties and the Court on historical factors does sometimes obstruct understanding and lead to poor interpretations.

Finally, when the statutory text is reasonably determinate and reflects historically recent legislative deliberation, my cautious model of dynamic interpretation would not counsel further evolution of the statute to reflect changed circumstances of which the legislature was generally aware. For example, in Board of Governors v. Dimension Financial.Corporation, ${ }^{259}$ the issue was whether the Federal Reserve Board has jurisdiction over "nonbank banks" under the Bank Holding Com-

benefits, there had been no reported problems with administering the new rule and determining the value of contingent benefits. Id. at 645-46 (Marshall, J., dissenting).

${ }^{257}$ Id. at 644-45 (Marshall, J., dissenting). Professor Daniel Farber suggests that a statute such as this one, where there is some likelihood that Congress will sooner or later address the issue, might be treated differently from a general statute such as $\S$ 1983, which will probably not be amended. I agree that greater caution should be shown by courts in the former situation, but a pure wait-and-see attitude typically involves more waiting than seeing.

${ }^{288}$ See, e.g., Offshore Logistics, Inc. v. Tallentire, 106 S. Ct. 2485 (1986) (typical of the Court's willingness to bend statutory language in an area otherwise dominated by federal common law); Lowe v. SEC, 472 U.S. 181 (1985) (typical of the Court's dynamic interpretation of regulatory statutes to reflect changed constitutional limitations); Garcia v. United States, 469 U.S. 70 (1984) (typical of the Court's dynamic interpretation of old criminal laws to update them to current concerns); SEG v. Jerry T. O'Brien, Inc., 467 U.S. 735 (1984) (typical of the Court's dynamic interpretation of old statutes, in this case the Securities Act of 1933 and the Securities Exchange Act of 1934 , to reflect new statutory developments).

259106 S. Ct. 681 (1986). 
pany Act. ${ }^{280}$ The statute gives the Board jurisdiction over "banks," which it defines as any institution that "(1) accepts deposits that the depositor has a legal right to withdraw on demand, and (2) engages in the business of making commercial loans."261 The Board asserted jurisdiction over nonbank banks, or institutions that accept deposits that are "as a matter of practice" payable on demand (notwithstanding technical provisions requiring prior notice) and that use those deposits to purchase commercial paper, certificates of deposit, and similar money market instruments. The Board justified this action on the basis of significant change in the societal circumstances of bank regulation: after Gongress opened up competition for deposits in 1980 nonbank banks exploded into the market, thereby threatening the general system of banking regulation administered by the Board. ${ }^{262} \mathrm{~A}$ unanimous Supreme Court overturned the Board's assertion of jurisdiction because it went beyond the "plain meaning" of the statute.

The model of dynamic statutory interpretation explicated in this Article would support the Court's approach in Dimension Financial. While both the societal and legal context of the statute changed in ways probably not anticipated by Congress, the statutory language is relatively determinate. The statute's technical requirement that the institution must "accept[] deposits that the depositor has a legal right to withdraw on demand,"26s does exclude nonbank banks. The historical perspective lends further (and decisive) support to the Court's decision, for it suggests that Congress expected the technical language to be stringently enforced. In fact, Congress has carefully amended this provision twice in the last thirty years to liberalize this language. ${ }^{204}$ The apparent legislative compromise is not one that the Court should alter, particularly in light of recent legislative efforts to curtail, rather than expand, the Board's jurisdiction.

Because the Supreme Court often informally follows something approaching this cautious model of dynamic statutory interpretaton, this model would not change the results in many cases. The model would, however, introduce greater candor and more consistent analysis into the Supreme Court's jurisprudence of statutory interpretation. It would also contribute to a long-needed doctrinal change, liberalization of the rule that prior interpretations of statutes should almost never be

28012 U.S.G. $\S 1841$ (1982).

28112 U.S.C. $\S 1841$ (c) (1982).

28249 Fed. Reg. 794, 834-36 (1984); see Dimension Financial, 106 S. Ct. at 685 n.3.

${ }^{263} 12$ U.S.C. $\$ 1841$ (c) (1982).

284 Dimension Financial, $106 \mathrm{~S}$. Ct. at 684-85. 
overruled. ${ }^{268}$ Part of the rationale behind this rule is the presumption that an earlier interpretation of legislative intent is more reliable than a later one because the earlier court is historically closer to the legislature that enacted the statute. Once statutory interpretation is divorced, at least at times, from the search for original intent, this reason for respecting statutory precedents is negated. Of course, prior statutory precedents should normally be upheld, based upon the same precepts of stare decisis that apply to common law precedents; they should simply not be given any greater deference than is necessary. ${ }^{266}$

\section{B. Dynamic Interpretation and the Gambit of Hart and Sacks}

My model of dynamic interpretation is akin to the Hart and Sacks purpose-of-the-statute approach ${ }^{267}$ because I join Hart and Sacks in their rejection of the mythology of intentionalism and their positing of a progressive blend of formalism and realism. Moreover, I would usually agree with the results reached by the Supreme Court when it has utilized a purpose approach, as it did in Weber. On the other hand, my approach differs significantly in theory from that of Hart and Sacks, because I do not make the same idealized assumptions as Hart and Sacks do, and I am willing to admit that courts make policy choices in

265 Liberalization of this rule is the subject of a work in progress, W. Eskridge, Overruling Statutory Precedents (Feb. $1987 \mathrm{draft}$ ). The stare decisis rule is suggested by Justice Brandeis' dissent in Burnet v. Coronado Oil \& Gas Co., 285 U.S. 393, 40607 (1932), and is commonly invoked by the Court. See Square D Co. v. Niagara Frontier Tariff Bureau, 106 S. Ct. 1922, 1930-31 \& n.34 (1986); Miller v. Fenton, 106 S. Ct. 445, 452 (1985); Illinois Brick Co. v. Illinois, 431 U.S. 720, 736-37 (1977). On the other hand, the Court has arguably violated the rule in such cases as Monell v. New York Dep't of Social Servs., 436 U.S. 658, 695 (1978) (overruling the more than decade-long interpretation that municipalities could not be sued under $\S 1983$ ); Continental T.V., Inc. v. GTE Sylvania Inc., 433 U.S. 36, 47 (1977) (replacing the ten-year-old rule on the per se rule of illegality of restrictions on sale of goods after title has passed with a rule weighing the reasonableness of the restriction); Lodge $76 \mathrm{v}$. Wisconsin Employment Relations Comm'n, 427 U.S. 132, 154 (1976) (explicitly overruling the Briggs-Stratton doctrine which the Court pronounced in 1949 to permit states to regulate some strike activities irrespective of the NLRA).

${ }^{268}$ For example, if the Supreme Court in 1872 had interpreted $\S 1983$ to exclude punitive damage awards, based upon the common law in that decade, I would not consider that statutory precedent compelling one hundred years later. Not only has the common law context of $\S 1983$ changed, but the statute's purposes and operational context have changed as well. For instance, Monroe v. Pape, 356 U.S. 167, 187 (1961), overruled on other grounds, Monell, 436 U.S. at 701, introduced a new era for the statute. Hence, I would overrule that 1872 precedent as inconsistent with the modern trend in $\S 1983$ cases. On the other hand, if Monroe had never been decided, and $\S 1983$ had remained in disuse, I would probably leave the 1872 precedent intact, based simply upon general principles of stare decisis.

${ }_{267}$ See infra note 275 and accompanying text. 
hard cases of statutory interpretation.

The Hart and Sacks approach to statutory interpretation rested upon the assumptions that statutes have rational purposes and that judges can find and apply those purposes:

In interpreting a statute a court should: 1 . Decide what purpose ought to be attributed to the statute and to any subordinate provision of it which may be involved; and then 2. Interpret the words of the statute immediately in question so as to carry out the purpose as best as it can . . . . ${ }^{268}$

These were appealing assumptions in the 1950's, but today they are highly controversial. ${ }^{269}$ Public choice scholarship and institutional political theory, such as Kingdon's "garbage can model," have demonstrated that many legislative acts are not "rational" or "purposive" in the way Hart and Sacks used the terms. ${ }^{270}$ Indeed, the "typical" statute is one with a congeries of purposes and policies-not all of them entirely rational and not all of them consistent with one another!

Recall the analysis of the Title VII cases in the first Part of this Article. The simple Hart and Sacks approach to those cases strikes me as misleading and inadequate. To proclaim that the single purpose of Title VII was to provide jobs for minorities, as the Court did in Weber, is to misstate history. There were many purposes embodied in Title VII-some of them, such as the sex discrimination provision, added quite adventitiously-and if there were a single overriding purpose, it would be to create a color-blind society, a purpose invoked most persuasively by the dissenting opinion. ${ }^{271}$ Moreover, no matter which purpose one accepts in Weber, it would seen to be at odds with the statutory provision protecting seniority rights at issue in Stotts. Title VII embodies a curiously shaped vision of fair employment, one that is susceptible to a Hart and Sacks analysis only through the most tortured reading of the statute. The model of dynamic statutory interpretation developed in this Article is based upon a more realistic view of the legislative process and is more defensible under our axiomatic assumption of legislative supremacy in a representative democracy.

${ }^{268}$ H. HART \& A. SACKS, supra note 4, at 1411; see id. at 1185, 1414-15, 1200.

${ }^{269}$ For an extensive analysis of the rise and fall of the Hart \& Sacks approach to legisprudence, see Eskridge \& Frickey, Legislation Scholarship and Pedagogy in the Post-Legal Process Era, 48 U. PITT. L. REv. 691, 694-725 (1987).

270 An excellent and critical analysis of this scholarship and its bearing on legal matters is Farber \& Frickey, supra note 13. See also W. Eskridge \& P. FRICKEY, supra note 149.

${ }^{271}$ United Steelworkers v. Weber, 443 U.S. 193, 219 (1979) (Rehnquist, J., dissenting). 
Notwithstanding its logical flaws, which are more pronounced today than they were in the 1950's, the Hart and Sacks approach to statutory interpretation may yet be appealing because of its progressive formalism. That is, by focusing on legislative purpose, Hart and Sacks would permit statutory law to grow and develop because legislative purpose is a more elastic concept than legislative intent, and at the same time to sustain its legitimacy by reference to original legislative expectations, legislative purpose being the next best thing to specific legislative intent. Judges can create new law without having to admit it. However politically attractive such a progressive formalism might be, it is an uncomfortable position for judges to take. Candor alone argues in favor of an approach that admits the nature and considerations involved in judicial lawmaking. ${ }^{272}$

Additionally, the Hart and Sacks "gambit" has more often than not been used to the Court's discredit, having contributed to sloppy opinions such as the majority opinion in Weber. Consider a further example, the Court's decision in Bob Jones University v. United States. ${ }^{273}$ In Bob Jones, the issue was whether a nonprofit private school prescribing racially discriminatory admissions standards could qualify as an institution "organized and operated exclusively for religious, charitable, . . . or educational purposes" and hence, be exempt from income taxes pursuant to section 501(c)(3) of the Internal Revenue Code. ${ }^{274}$ The quoted statutory language originated in the 1894 income tax law and was included in every subsequent version of the federal income tax law. Petitioner Bob Jones University argued that its activities "exclusively for . . . educational purposes" entitled it to exemption under the plain meaning of the statute.

The Court rejected this argument and held that the University's racially discriminatory admissions policies precluded its receiving the statutory exemption. To reach this result, the Court employed the classic Hart and Sacks purpose-of-the-statute approach. ${ }^{275}$ The Court found the general purpose of section 501, and its companion provision section 170 (which allows taxpayers to deduct contributions to section 501 organizations ${ }^{276}$ ), to be the provision of tax benefits to organizations serving "charitable purposes" because such organizations afford a

272 Judge Posner writes eloquently on the subject of candor in his article on realism and formalism in statutory cases. See Posner, supra note 7.

273461 U.S. 574 (1983).

274 I.R.C. \& 501(c)(3) (1982).

278 See 461 U.S. at 586 ("[A] court should go beyond the literal language of a statute if reliance on that language would defeat the plain purpose of the statute ....").

${ }^{276}$ I.R.C. § 170 (1982 \& Supp. III 1985 \& West Supp. 1987). 
substantial benefit to society. ${ }^{277}$ This purpose would be thwarted if the exemption were extended to organizations that are not "charitable," which the Gourt read to exclude any organization whose activity is "contrary to a fundamental public policy."278 Finding the racially discriminatory admissions standards of Bob Jones University to be contrary to fundamental federal policy, the Court concluded that the statutory purpose would be thwarted by extending the tax exemption to organizations such as Bob Jones University. ${ }^{279}$

The Court's opinion is commendable in that it disclaimed any reliance on original legislative intent, ${ }^{280}$ but its purpose analysis is puzzling and unpersuasive. To begin with; the Court oversimplified the legislative purpose of section 501 exemptions. Other Supreme Court decisions suggest that the main purpose of section 501 was to contribute "to the diversity of association, viewpoint, and enterprise essential to a vigorous, pluralistic society,"281 and a perusal of the 106,000 organizations receiving the exemption in 1982 suggests that this is a more realistic goal than that posited by the Bob Jones Court. ${ }^{282}$ Moreover, the Court's opinion treated legislative attention to the subject arbitrarily. On the one hand, the Court emphasized the enactment of civil rights legislation expressing public concern about racial discrimination in education. On the other hand, the Court all but ignored the argument that Congress had had numerous opportunities to extend this policy to private educational institutions but had never done so: ${ }^{283}$

Bob Jones is a classic case in which the Hart and Sacks approach is invoked by the Court as a substitute for careful analysis. The Court obviously created new law in this case, going well beyond what Congress had done. Can it be justified? The best justification is the dynamic, deliberative one suggested by the concurring opinion of Justice

\footnotetext{
277 Bob Jones, 461 U.S. at 587, 591-92.

278 Id. at 592.

279 Id. at $592-96$.
}

280 "In 1894, when the first charitable exemption provision was enacted, racially segregated educational institutions would not have been regarded as against public policy." Id. at 593 n.20.

${ }^{281}$ Id. at 609 (Powell, J., concurring) (quoting Walz v. Tax Comm'n, 397 U.S. 664, 689 (1970) (Brennan, J., concurring)).

${ }^{282}$ See id. at 606, 609-10 \& n.3 (Powell, J., concurring); Walz v. Tax Comm'n, 397 U.S. 664, 689 (1970) (Brennan, J., concurring).

${ }^{283}$ Bob Jones, 461 U.S. at 612, 615-17, 620-22 (Rehnquist, J., dissenting); see Freed \& Polsby, Race, Religion \& Public Policy: Bob Jones University v. United States, 1983 SuP. CT. Rev. 1, 8-12. Thus the civil rights statutes cited by the Court prohibited discrimination in public, but not private, schools. Section 501 itself was amended many times, yet Congress never added the caveat created by the Court. Indeed, Congress added $\$ 501(j)$ to deny the exemption to social clubs practicing racial discrimination, but again failed to address the situation of private schools. 
Powell. ${ }^{284}$ The statutory language is open-ended and the original history of the statute is of little relevance because circumstances have changed radically. Hence, the evolutive perspective is critical. Our current attitudes about giving tax breaks to racially discriminatory institutions are decisively influenced by the public deliberation in which we have engaged since $B$ rown $n^{285}$ and the various civil rights statutes. To the extent we have policymaking discretion, we should exercise it to penalize discrimination. Probably for this reason, the Internal Revenue Service, the agency charged with implementing section 501, adopted the antidiscrimination policy in 1970 , which triggered a far-reaching policy debate in Congress during the 1970's. Ultimately, Congress rejected all efforts to overturn the agency's action and Justice Powell found some evidence that informed opinion embraced the agency's new interpretation. ${ }^{286}$ The Court's result capped a decade of deliberation on this public issue by putting the antidiscrimination exception in the statute.

One may disagree with this dynamic policy analysis, but it is more edifying than the obfuscating Hart and Sacks approach to the statute posited by the Court. At least it is honest: the Court's commitment to the public value of a nondiscriminatory society is important enough to influence its interpretation of an ambiguous statute. Congress may compromise that public value, within certain constitutional limits, but until it does so the Court should continue the uniquely public deliberative process that it started in Brown.

The broader point to be drawn from this analysis is that the $\mathrm{Su}-$ preme Court often purports to rely on original legislative purposes in interpreting statutes, while in fact using the Hart and Sacks purpose analysis to bend statutory language to satisfy current policy goals. ${ }^{287}$ This typically leads to a sharp dissenting opinion that dredges up historical background material to disprove the Court's assertions about the historical understanding. The Court, in turn, often responds with its own historical material. What is too often lost in such an exchange of historical arcana is a careful analysis of the statutory text, the evolving

284 Bob Jones, 461 U.S. at 606 (Powell, J., concurring).
285 Brown v. Board of Educ., 347 U.S. 483 (1954).
${ }^{286}$ See 461 U.S. at 607 \& n.2 (Powell, J., concurring).
287 For some recent examples, each of which provoked a heated dissenting opinion, see Midlantic Nat'l Bank v. New Jersey Dep't of Envtl. Protection, 106 S. Ct. 755, 762 (1986); Lowe v. SEC, 472 U.S. 181 (1985); Washington Metro. Area Transit Auth. v. Johnson, 467 U.S. 925 (1984); Dickman v. Commissioner, 465 U.S. 330, 344 (1984); Southland Corp. v. Keating, 465 U.S. 1 (1984); Bell v. United States, 462 U.S. 356 (1983); Watt v. Western Nuclear, Inc., 462 U.S. 36 (1983); Jefferson County Pharmaceutical Ass'n, Inc. v. Abbott Laboratories, 460 U.S. 150 (1983); cf. Montana v. Blackfeet Tribe of Indians, 471 U.S. 759 (1985) (using policy presumptions to same effect). 
policies currently of importance to the statute, and even the facts of the case. What I urge-and what the Court often displays-is candor about the marginal importance of the historical perspective. Then, rigorous deliberation can be given to the pertinent policy choices that the Court must make. ${ }^{288}$

\section{Dynamic Interpretation and Dworkin's Law as Integrity}

Notwithstanding theoretical and practical problems, the Hart and Sacks modified intentionalist approach to statutory interpretation is a significant improvement over the intentionalist approach. Similarly, Dworkin's theory of statutory interpretation, set forth in some detail in Law's Empire, ${ }^{289}$ is a great improvement over the Hart and Sacks approach. Dworkin's theory of statutory interpretation is part of his general theory of "law as integrity," in which he argues that all law, including common law, statutes, and the Constitution, is a continuous process of interpretation. Dworkin has in an important way challenged scholars and judges to think about statutory interpretation as an ongoing process focusing on the present, and has linked his theory of statutory intepretation with a comprehensive theory of law.

Dworkin's argument is rich and complex, much more complete than the summary here. Dworkin posits that "integrity in legislation," which requires lawmakers to try to make the total set of laws morally coherent, is "so much part of our political practice that no competent interpretation of that practice can ignore it."280 The legislative principle of integrity not only describes a key impulse in our polity, Dworkin argues, but is central to the legitimacy of our government. ${ }^{291}$ Like justice and fairness, integrity in law contributes to the fraternity of the

288 For examples of the Court's most candid admission that it is drawing upon current, rather than historical, policy purposes, see Bateman Eichler, Hill Richards, Inc. v. Berner, 472 U.S. 299 (1985) (applying "public policy principles" in interpreting insider trading provisions of federal securities laws); Landreth Timber Co. v. Landreth, 471 U.S. 681 (1985) (looking at current expectations in determining the definition of stock under the Securities Exchange Act of 1933); Alexander v. Choate, 469 U.S. 287 (1985) (using current public interest in broadly interpreting the Rehabilitation Act of 1973); SEC v. Jerry T. O'Brien, Inc., 467 U.S. 735 (1984) (using current policy concerns to give meaning to provisions of the securities laws); TWA v. Franklin Mint Corp., 466 U.S. 243 (1984) (looking at the Par Value Modifications Act through the lens of modernity).

${ }^{289}$ R. Dworkin, supra note 1, at 45-86, 176-275, 313-54, sets forth Dworkin's theory. Dworkin had developed the main contours of his theory of statutory interpretation in A Matter of Principal, supra note 10 (analyzing Weber), and R. Dworkin, supra note 121 (statutory interpretation as a "chain novel").

${ }^{280} \mathrm{R}$. DwORKIN, supra note 1 , at 176.

291 Id. at $190-92$. 
body politic, the moral community that bonds us together. ${ }^{292}$ Given the existence and desirability of integrity in legislation, Dworkin defines "integrity in adjudication" as the requirement that judges "treat our system of public standards as expressing and respecting a coherent set of principles, and, to that end, to interpret these standards to find implicit standards between and beneath the explicit ones."293 Integrity in adjudication means that judges must "identify legal rights and duties ... on the assumption that they were all created by a single author-the community personified-expressing a coherent conception of justice and fairness."204

Under law as integrity, "propositions of law are true if they figure in or follow from the principles of justice, fairness, and procedural due process that provide the best constructive interpretation of the community's legal practice."205 Dworkin views interpretation as akin to a "chain novel," in which a common law precedent or a legislated statute is the first, and foremost, chapter in the novel and subsequent authors, usually judges, are called upon to add new chapters. The goal of the seriatim contributors to the chain novel is to make the novel the best, most internally coherent, work it can be. ${ }^{298}$ Thus, the interpreter of statutes "interprets not just the statute's text but its life, the process that begins before it becomes law and extends far beyond that moment. He aims to make the best he can of this continuing story, and his interpretation changes as the story develops."297

Dworkin's vision of legislation is romantic, perhaps the noblest approach to the subject in print. But is the legislative principle of integrity a fair statement of our political morality? I have some initial doubts, although perhaps they are provisional.

To begin with, I doubt that Dworkin's view of legislation is or can be accurate. To establish his argument that the legislative principle of integrity is instinctive in our political system, Dworkin points to our collective disdain for "checkerboard statutes," those that treat different groups of people in different ways, without a clear principled reason. ${ }^{298}$ Such statutes may be an inherent part of our system, however. Title VII is certainly as principled a statute as any we have, and its principle of equal employment opportunity is a great principle. But it is riddled with special exceptions concerning religious institutions, members of

\footnotetext{
292 Id. at $195-215$.

${ }^{208}$ Id. at 217.

294 Id. at 225.

298 Id.

290 Id. at 228-75.

297 Id. at 348.

${ }^{298}$ Id. at $178-84$.
} 
the Communist Party, bona fide seniority systems, government entities and subdivisions, and small businesses. ${ }^{298}$ Nor is Title VII an anomaly: most detailed statutes contain such exceptions, and most areas of statutory law are similarly riddled with exceptions. ${ }^{300}$ While our system of law certainly aspires to a substantial amount of policy coherence, public choice theory suggests the inevitability of checkerboard patterns. ${ }^{301}$

Most statutes cannot pass through the legislative juggernaut without trading off some of their policy coherence to attract support or ameliorate oppostion. For example, Title VII surely included section 703(h), which created an exception for bona fide seniority systems, to attract or retain union support. ${ }^{302}$ Most statutes, standing alone, are compromises. Over time, of course, Congress amends the statute and creates new but related ones. Not only do the new statutes have their own internal inconsistencies, but they are often inconsistent with the thrust of earlier statutes because the public concerns are different or the political circumstances different. This is the policy fragmentation about

209 Section 703(a)-(d) of the Civil Rights Act, 42 U.S.C. $\S 2000 \mathrm{e}-2$ (a) to -2 (d) (1982), sets forth the basic nondiscrimination provisions, but other sections create various exceptions. See id. $\$ \S 2000$ e(b) (definition of "employer" excludes small firms, - governmental entities, etc.), $2000 \mathrm{e}-1$ (exemption for religious educational institutions), $2000 \mathrm{e}-2$ (f) (special rule for members of the Communist Party), 2000e-2(h) (special exception for bona fide seniority systems).

${ }^{300}$ See, e.g., I.R.C. § 501 (1982 \& West Supp. 1987) (excepting certain "exempt" organizations from the general rule of federal income taxation); 15 U.S.C. $\S 77$ (d) (1982) (excepting various "exempt transactions" from the general requirement of registration prior to the sale of securities).

${ }_{301}$ The economists' versions of the public interest theory of regulation provide convincing explanations of the varied pattern of political choices. See Becker, $A$ Theory of Competition Among Pressure Groups for Political Influence, 98 Q.J. EcoN. 371 (1983) (positing a theory of political redistribution of income and other public policies due to competition among "pressure groups" for political influence); Posner, Theories of Economic Regulation, 5 Bel. J. ECoN. \& MGMT. SCI. 335 (1974) (noting the promise of the economic version of the interest group theory, which posits that regulation is a service supplied to effective political interest groups); Stigler, The Theory of Economic Regulation, 2 BeLl. J. EcoN. \& MGMT. ScI. 3 (1971) (theorizing that politically influential economic groups demand and acquire regulation by the government that is designed to benefit that particular group). For an excellent judicial opinion canvassing the checkerboard nature of railway labor laws, see Burlington Northern v. Brotherhood of Maintenance of Way Employees, 793 F.2d 795, 800-02 (7th Cir. 1986), affd, 55 U.S.L.W. 4576 (U.S. April 28, 1987).

${ }_{302}$ The provision reads, in pertinent part, "it shall not be an unlawful employment practice for an employer to apply different standards of compensation, or different terms, conditions, or privileges of employment pursuant to a bona fide seniority or merit system." Givil Rights Act of 1964 , Pub. L. No. 88-352, § 703(h), 78 Stat. 241, 257 (1964) (codified at 42 U.S.C. $§ 2000$ e-2(h) (1982)). The House Minority Report on the proposed Act, which did not include $\$ 703(\mathrm{~h})$, warned that the act would "destroy" seniority systems. H.R. REP. No. 914, 88th Cong., 1st Sess. $71-72$ (1964). Ultimately, the "Mansfield-Dirksen" compromise was struck with several amendments, which added $\S 703(\mathrm{~h})$ to the bill. See 110 ConG. Rec. S11926 (daily ed. May 26, 1964) (statement of Sen. Dirksen). 
which institutional political scientists complain: statutes tend to be ad hoc, and over time a series of ad hoc statutes can be distressingly incoherent. While I think courts can mitigate the incoherence, I do not believe courts can substantially erase it. ${ }^{303}$

Moreover, the checkerboard pattern of statutes appeals to two values built into our political system: reliance and intensity of preferences. The reliance value means that once a checkerboard policy has been established, courts or the legislature may refuse to broaden it, but neither should they take it away. ${ }^{304}$ We also value intensity of preferences: if one group of Americans wants nothing in life but a bloated pension system, better than that assured by Social Security, the system will often give it to that group. The reliance value will then preserve that special benefit over time. Many Americans will consider this arrangement "fair," so long as they believe that their own group's most intense preferences will also be satisfied. ${ }^{305}$

My doubts about Dworkin's argument are reinforced by the insights of critical and feminist legal scholars. Where Dworkin sees patterns of principle in some statutes, critical and feminist scholars see patterns of oppression, subordination, and mystification. For example, Dworkin could argue that our society is deeply committed to battling employment discrimination based upon sex. This does seem to be a principle that gives coherence to a range of statutes and judicial decisions, including Title VII and its rich case law. Yet this coherence may be superficial, since Professor Catharine MacKinnon argues that Title VII has not only failed to protect women against employment discrimination, but has sanctioned it. ${ }^{306}$ Professor Susan Estrich's recent article demonstrates the sexism and incoherence of the criminal law of rape and includes in her indictment "reformist" legislation such as the Model Penal Code. ${ }^{307}$ These and other critical studies not only suggest

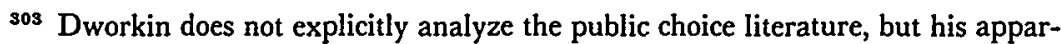
ent response is that some political compromises are of course inevitable and that a compromise statute generally subserving principle (such as Title VII) is better than no statute at all. See R. DwORKIN, supra note 1, at 217-18. This response severely underestimates the pervasiveness of checkerboard statutes.

sot The reliance value also explains why judicial doctrine is often incoherent; stare decisis prevents courts from overruling their precedents, but it does not require courts to expand the reasoning of obsolete precedents to new fact situations. Thus, the obsolete past and the novel present coexist over time.

${ }_{305}$ But see R. DwORKIN, supra note 1, at 178-84 (suggesting that on occasion the most intense prefernce leads individuals to a ready compromise, which of itself compromises the integrity of the preference).

308 See C. MacKinnon, Sexual Harassment of Working Women (1979).

${ }^{307}$ Estrich, Rape, 95 YALE L.J. 1087 (1986); see Olsen, Statutory Rape: A Feminist Critique of Rights Analysis, 63 TEx. L. Rev. 387 (1984); Peller, supra note 185, at $1187-91$. 
the incoherence of various fields of law, ${ }^{308}$ implying that law does not possess the integrity envisioned by Dworkin, but also would question any approach which sought complete coherence from the oppressive precedents of the past.

On the one hand, then, Dworkin's principles of integrity do not adequately describe what American legislatures do or the statutes they produce. On the other hand, even the aspirational appeal of Dworkin's argument-that any inconsistencies created by the legislature do not represent our society at its best, and courts ought to weave statutory checkerboards into a coherent pattern-not only runs against the grain of the common assumption of legislative supremacy, but is also potentially very conservative because it might propagate morally outmoded values. Notwithstanding these problems, I concur with Dworkin's quest for coherence in the law in two important respects. First, there are certain public values-such as nondiscrimination and freedom of speech, press, and religion-which courts will protect from statutory encroachment, often through strained statutory interpretation. Second, courts will bend old statutes in response to more modern policies. In these ways, courts do lend greater coherence to statutory law; and I agree with Dworkin that this contributes to our government's overall legitimacy and worthiness. But I am doubtful that the courts can perform the truly utopian task of creating a general coherence in a corpus of legislated law which is inherently checkerboard in nature.

Dworkin distinguishes sharply between a rulebook community, in which citizens have a general commitment to obey rules created by government, and a community of principle, in which citizens see themselves governed, not just by political compromises, but by basic principles. $^{309}$ The latter seems to me a worthier sense of community. But the distinction oversimplifies our polity, which has elements of both communities: we are committed to a rulebook mentality as to myriad things, but we also have common values that bond us together. My essential disagreement with Dworkin is that I do not think law can transform our community from a hybrid into a community of principle.

There is a telling contrast between various conceptualizations of judges. The judge in many of Dworkin's works is called Hercules, suggesting an all-powerful, omniscient figure who roams the fields of law

${ }^{308}$ See, e.g., Kennedy, The Structure of Blackstone's Commentaries, 28 Buffalo L. REv. 205 (1979) (discussing the conflict between individual freedom and the communal coercive action thought necessary to achieve this state); Kennedy, Form and Substance in Private Law Adjudication, 89 HARv. L. Rev. 1685 (1976) (discussing conflict in law of contracts and in private law systems generally).

sog R. DworkIN, supra note 1 , at 209-11. 
and reaps magisterial coherence from them. Admittedly a caricature, Hercules is like a utopian planner, the noblest of figures. But this model is not much like the judges whom I have known. Instead, judges interpreting statutes according to something like the dynamic model in this Article are like diplomats acting upon orders from their national foreign service. ${ }^{310}$ These diplomats must often apply ambiguous or outdated communiqués to unforeseen situations, which they do in a creative way, not strictly constrained by their orders. But they are, at bottom, agents in a common enterprise, and their freedom of interpretation is bounded by the mandates of their orders, which are not necessarily consistent or coherent over time, or even at any one time. ${ }^{311}$

Judges 'who interpret statutes are sometimes Hercules, as Chief Justice Earl Warren and his colleagues perhaps were in Brown, ${ }^{\mathbf{3 1 2}}$ but most often they are diplomats. Under the current assumptions of our society this is not considered a bad thing: judges who think they are Hercules, unless they are very clever, are frequently reversed. The role of the faithful public servant who applies decency and fairness to a system fraught with incoherence is a noble role. It is an everyday nobility, not the storybook nobility of Utopia, and more to be cherished for that. ${ }^{313}$

\section{ConCLUSION}

My purpose in this Article is to challenge the often-stated (but less often believed) assumption that statutory interpretation is nothing but an exercise in finding answers that were fixed when the legislature originally enacted the statute. Like other texts, statutes are dynamic things: they have different meanings to different people, at different times, and in different legal and societal contexts. It is a significant departure from current doctrine to assert, as I do, that federal courts should interpret statutes in light of their current as well as historical context. Dynamic interpretation is most appropriate when the statute is old yet still the source of litigation, is generally phrased, and faces sig-

s10 Professor Daniel Farber suggested this analogy to me in a letter commenting on this Article.

s21 Judge Posner analogizes judges to platoon commanders who must interpret and apply battlefield orders. See Posner, supra note 7, at 189-92. I find this, too, an illuminating and imaginative metaphor which is similar to the one explicated in text.

${ }^{312}$ Brown v. Board of Educ., 347 U.S. 483 (1954).

s13 I am thinking here of Edward Weinfeld, a judge in the Southern District of New York for the last 36 years, and still actively doing justice from 5:00 a.m. until 5:00 p.m. six or seven days a week. Judge Weinfeld is not Hercules, but his day-in and dayout quest for justice within the confines of statutes and judicial precedents is the noblest thing a judge, or any other public servant, can do. 
nificantly changed societal problems or legal contexts. Dynamic interpretation is least appropriate when the statute is recent and addresses the issue in a relatively determinate way.

As I have emphasized in this Article, my model of dynamic interpretation is a cautious one. It is, of course, possible to defend a more iconoclastic approach to the issue. ${ }^{314}$ Critical scholars argue that textual meaning is not so determinate as $I$ assume in this Article. ${ }^{918}$ These approaches to interpretation are more difficult to justify in light of current assumptions about legislative supremacy and statutory interpretation. They would have more far-reaching effects than my proposal. Nevertheless, I invite expansion upon this model. In the spirit of the legal realists, I believe that candid and constructive policy debate will enrich the long neglected discipline of statutory interpretation. 
HeinOnline -- 135 U. Pa. L. Rev. [1556] 1986-1987 